DANMARKS GEOLOGISKE UNDERSØGELSE

II. Rakke. Nr. 105

Geological Survey of Denmark. II. Series. No. 105

\title{
Foraminifera in Eemian deposits at Stensigmose, southern Jutland
}

BY

Peter Budach Konradi

DANSK SAMMENDRAG

Foraminiferer i eemien aflejringer

ved Stensigmose, Sydjylland

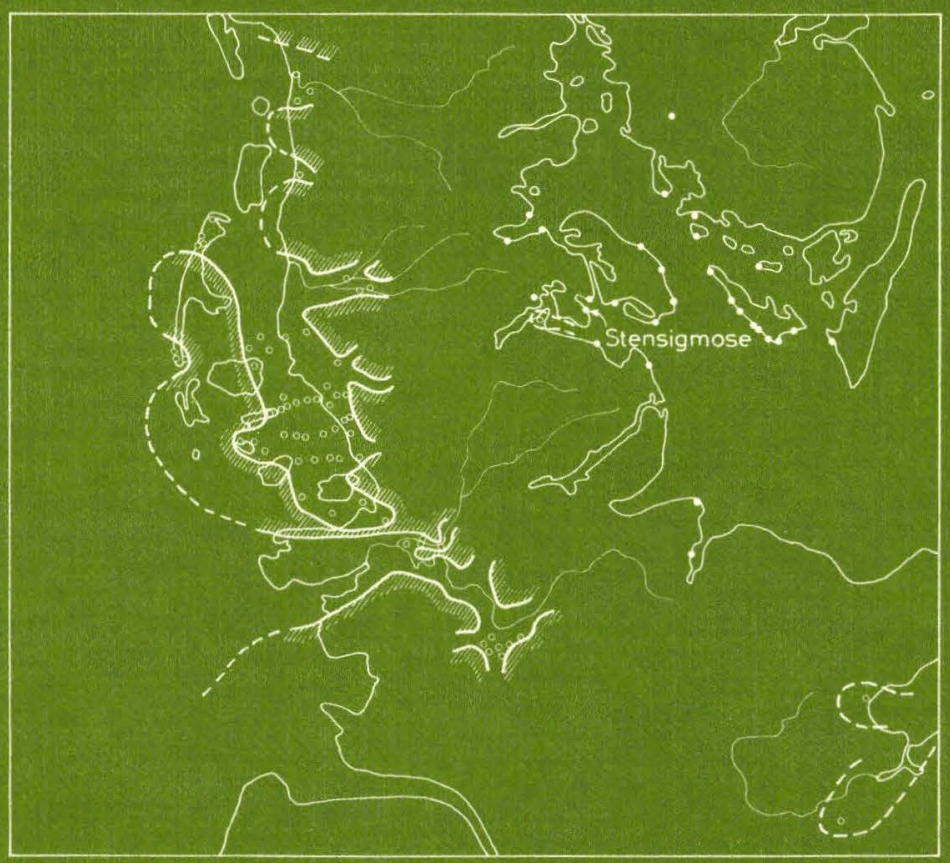

I kommission hos C. A. Reitzels Forlag. København 1976 
Danmarks Geologiske Undersøgelse. II. Række. Nr. 105

Geological Survey of Denmark. II. Series. No. 105

\section{Foraminifera in Eemian deposits at Stensigmose, southern Jutland}

By

Peter Budach Konradi

Dansk sammendrag:

Foraminiferer i eemien aflejringer

ved Stensigmose, Sydjylland

I kommission hos C. A. Reitzels Forlag København 1976 
D. G. U. II. rk. nr. 105

er sat med Fotosats Times

og trykt i offset i 1000 eksemplarer hos Andelsbogtrykkeriet i Odense.

Bogen er trykt på Thai-Cote, $115 \mathrm{~g}$ fra a/s De forenede Papirfabrikker. ISBN 8742106451

With 5 plates

Date of publication: $1976-01-28$ 


\section{Contents}

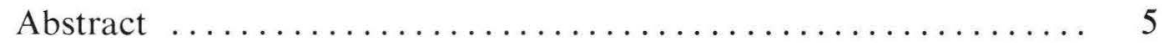

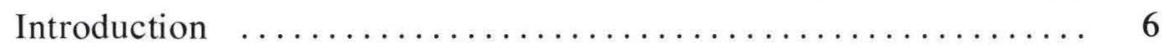

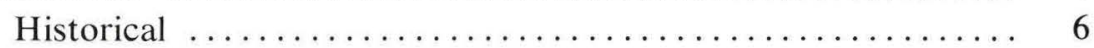

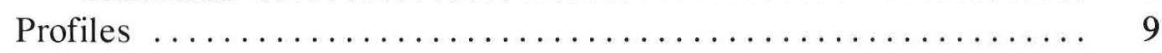

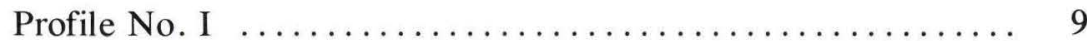

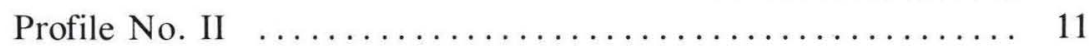

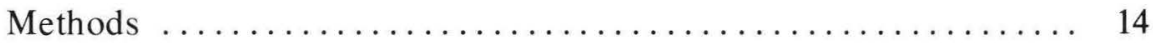

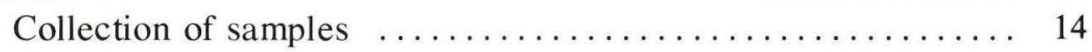

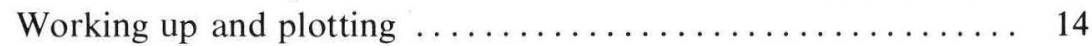

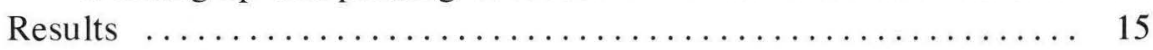

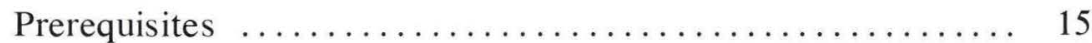

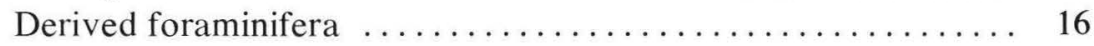

Environment ............................. 17

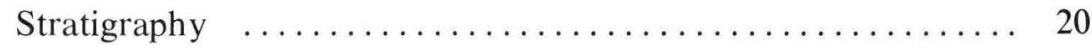

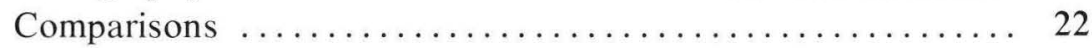

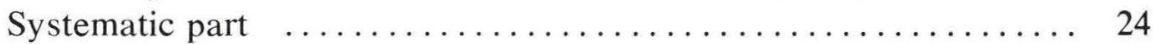

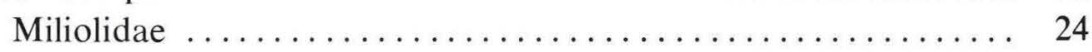

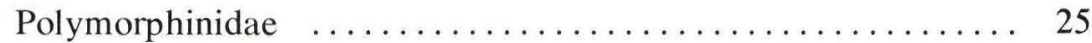

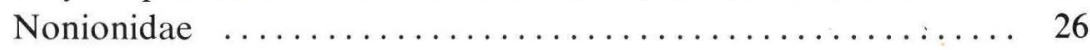

Discorbidae ............................. 27

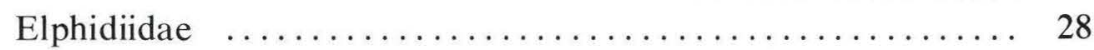

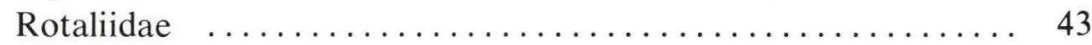

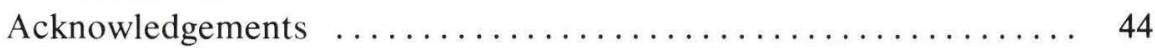

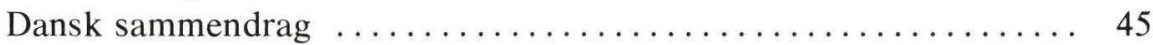

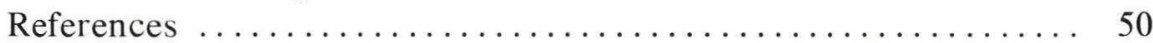

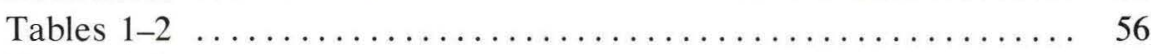

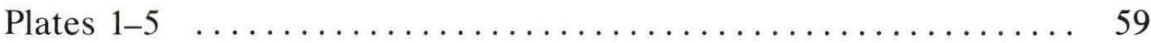




\section{Abstract}

The foraminiferal content of 57 samples from two sections in interglacial Eemian deposits of the cliff at Stensigmose, Broagerland in southern Jutland, have been investigated. Saalian glaciofluvial deposits and Eemian freshwater clay, underlying the marine sequence, were examined in order to check a contamination by reworked specimens from older deposits. The foraminiferal assemblages indicate that the marine sediments were deposited in shallow water. As the lower part of the strata was deposited, the water depth was increasing, but later on it was constantly decreasing. The lower part of the marine sequence was deposited during rising temperature conditions, reaching probably a little higher than today. Salinity was low throughout the deposition of these sediments, but higher than that of the present Baltic Sea. 


\section{Introduction}

The scope of this paper is to give a description of the foraminiferal assemblages of the Danish marine deposit from the last i.e. the Eem Interglacial, as represented as glacially displaced slices in the cliff at Stensigmose. Their affiliation to under- and overlying sediments has been investigated by starting profile No. I in the underlying Saaleian glaciofluvial deposits and Eemian freshwater deposits, and by continuing profile No. II upwards through overlying deposits from the Weichsel Glaciation.

\section{Historical}

An excellent review of papers dealing with the Eemian deposits of Denmark and adjacent areas of northern Germany and the Netherlands was given by Madsen, Nordmann \& Hartz (1908, pp. 3-43). Marine Eemian deposits were first described by J. G. Forchhammer in 1841 . He called these deposits Cyprina Clay, because they contained the bivalve Cyprina islandica (= Arctica islandica). I. F. Johnstrup in the 1870's was the first to realise the interglacial age of these deposits. Eemian foraminifera were described by Madsen (1895), Anderson (1898) and Munthe (1898) and listed by Harder (1900). The cliff at Stensigmose was first described by Gottsche (1904). $\mathrm{He}$ found that the Cyprina Clay at this locality, unlike at all others, was superposed by a sandy facies, which he termed the Tapes Sand, after the bivalve Tapes aureus occurring here. Madsen et al. (1908) gave a detailed description of all Danish localities with marine Eemian deposits and of their mollusc fauna. They concluded that Eemian deposits were found in situ in the Netherlands and western Schleswig, and as glacially displaced slices around the western Baltic Sea and in West- and East-Prussia. All these deposits yielded a particular mollusc fauna, which was characterized by the lusitanian species Divaricella divaricata, Syndosmya ovata, Gastrana fragilis, Haminea navicula and the now extinct Tapes aureus var. eemiensis (= Venerupis senescens).

The final placing of the Eemian deposits in the last i.e. the Saale-Weichsel Interglacial, was done by Nordmann (1928) on the basis of a series of 


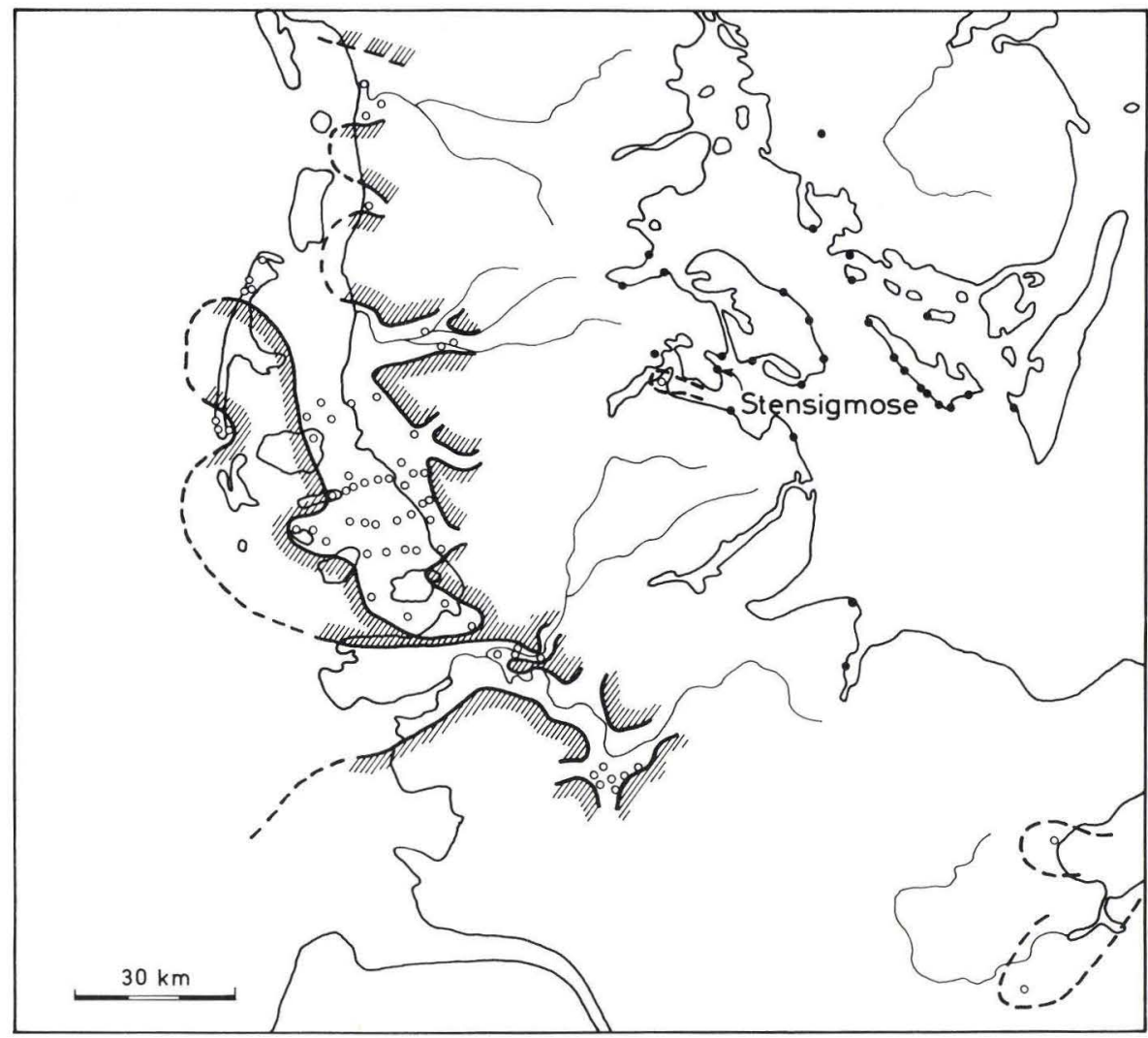

Fig. 1. Eemian deposits in Southwest Denmark and Schleswig-Holstein (after Madsen et al. 1908, Nordman 1928, Lafrenz 1963) and the extension of the Eemian sea along the west coast (after Gripp 1964). Black spots indicate occurrence as glacial slices. Circles indicate occurrence in borings.

borings southeast of Tønder, southwestern Jutland. His result was confirmed by Jessen \& Milthers (1928, p. 177) in pollen analyses from the freshwater clay underlying the marine sequence in the cliff at Stensigmose. They found that the marine transgression occurred in their pollen-zone $\mathrm{f}$, the zone with the mixed oak forest - Alnus, Tilia, Quercus and the Corylus maximum. This may correspond to zone 4 of Andersen (1965). Nordmann's result was again confirmed by Heck (1932) in borings from Oldenbüttel, western Holstein.

Eemian deposits of northern Germany were discussed by several authors, among them: Dittmer (1941, 1951), Heck \& Brockmann (1950), Brelie (1959), Sindowski (1959), Gehl (1961) and Lafrenz (1963). Their results were reviewed by Gripp (1964, p. 215). In the Eemian the marine trans. 
gression at the west coast of northern Germany occurred in the latest part of pollen-zone d, the zone with Pinus and Betula, or in the first part of pollen-zone e, the zone with Pinus and the start of the mixed oak forest with the Quercus maximum. This may correspond respectively to the end of zone 2 or the first part of zone 3 of Andersen (1965). At the Baltic coast of northern Germany the marine transgression occurred in pollen-zone $f$.

The location of Eemian deposits is indicated in Fig. 1.

The foraminifera of the Cyprina Clay of Ristinge Cliff, Ærø and Glamsbjerg were treated by Madsen (1895), who recorded 10 species and 3 subspecies. Munthe (1898) examined the foraminifera of a glacially displaced slice at Als Sønderskov and found 31 species and 1 subspecies belonging to the Quaternary and 34 Prequaternary species. Anderson (1898) investigated Ristinge Cliff and found 8 species and 2 subspecies. Harder (1900) listed 11 species found in two borings through Eemian deposits at Tønder. Lafrenz (1963) described the foraminiferal fauna in Eemian deposits of borings in western Schleswig-Holstein and of glacial slices at the Baltic coast. He recorded 59 species, which he considered to be of interglacial age. Only 16 of these species occurred in any abundance. Brodniewicz (1969) mentioned 14 foraminifera species from an Eemian deposit in Poland. The foraminifera faunas in marine Quaternary deposits in the German Democratic Republic were described by Wiegank (1972), who found 12 species in Eemian deposits. Konradi (in Petersen \& Konradi 1974) listed 17 species from a marine Quaternary deposit at Strandegaards Dyrehave, southeastern Sjælland, and referred it to the Eemian. Finally Konradi (in Bahnson, Petersen, Konradi \& Knudsen 1974, p. 46) investigated the foraminifera in the lower part of the Skærumhede II boring and referred the lower part of this to the Eemian. These strata were correlated with the upper part of the Turritella terebra Zone and the Abra nitida Zone of the Skærumhede Series. 


\section{Profiles}

The greater part of the coastal cliff at Stensigmose is built up of glacially dislocated slices. Many of these contain marine deposits from the Eem Interglacial. In 1928 the late Dr. Sigurd Hansen of the Geological Survey of Denmark made an unpublished survey of the cliff. This survey was kindly placed at my disposal by Dr. Sigurd Hansen. Even though the cliff has changed since 1928, it was possible to use this survey for identification of the general outline of the cliff, and especially the profile described by Gottsche (1904).

\section{Profile No. I}

The first profile, No. I, is located 130 m north of "Fiskerhuset", mentioned by Madsen et al. $(1908$, p. 83$)$. The profile is illustrated in Fig. 2. The peat horizon is situated $12 \mathrm{~m}$ above sea level. The cliff strikes north-south and the stratification in the profile dips $16^{\circ}$ to the south.

The basal part of the profile is partially covered by talus, and consists of typical glaciofluvial sand, showing cross bedding and ripple marks (samples 98 and 99). This sand contains subordinate layers of clay and of gravel. These strata end with a distinct ripple mark, the wavy surface of which is followed by the layering of the superposed clay. This clay consists of alternating layers of dark brownish to greyish clay and light grey clay. There are 54 double layers with an average thickness of $2-3 \mathrm{~cm}$. These are overlain by $30 \mathrm{~cm}$ of a greyish clay containing a few stones in the uppermost part.

After a distinct interface follows a peat-horizon (sample 102). It is contorted and has an irregular upper surface. It is overlain by a light greyishbrown calcareous gyttja (sample 104), which is followed by $75 \mathrm{~cm}$ of a grey-blue clay (samples 107 and 109). $25 \mathrm{~cm}$ below the top of this there is a layer with many brown spots, probably of organic origin. The clay is overlain by $150 \mathrm{~cm}$ of a yellow-brownish clay with a faint stratification and containing shells of molluscs (samples 110 to 115). In the upper part of this unit a $10 \mathrm{~cm}$ thick layer of sand occurs (sample 113), and above this some 


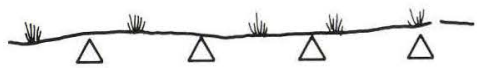

$\triangle \triangle \triangle \Delta \quad$ clayey till

$\triangle \triangle \triangle \triangle \Delta$

$\triangle_{-123}^{\triangle \Delta \Delta}-$

$\bullet 122$

- $121>$ light yellow-brown clay
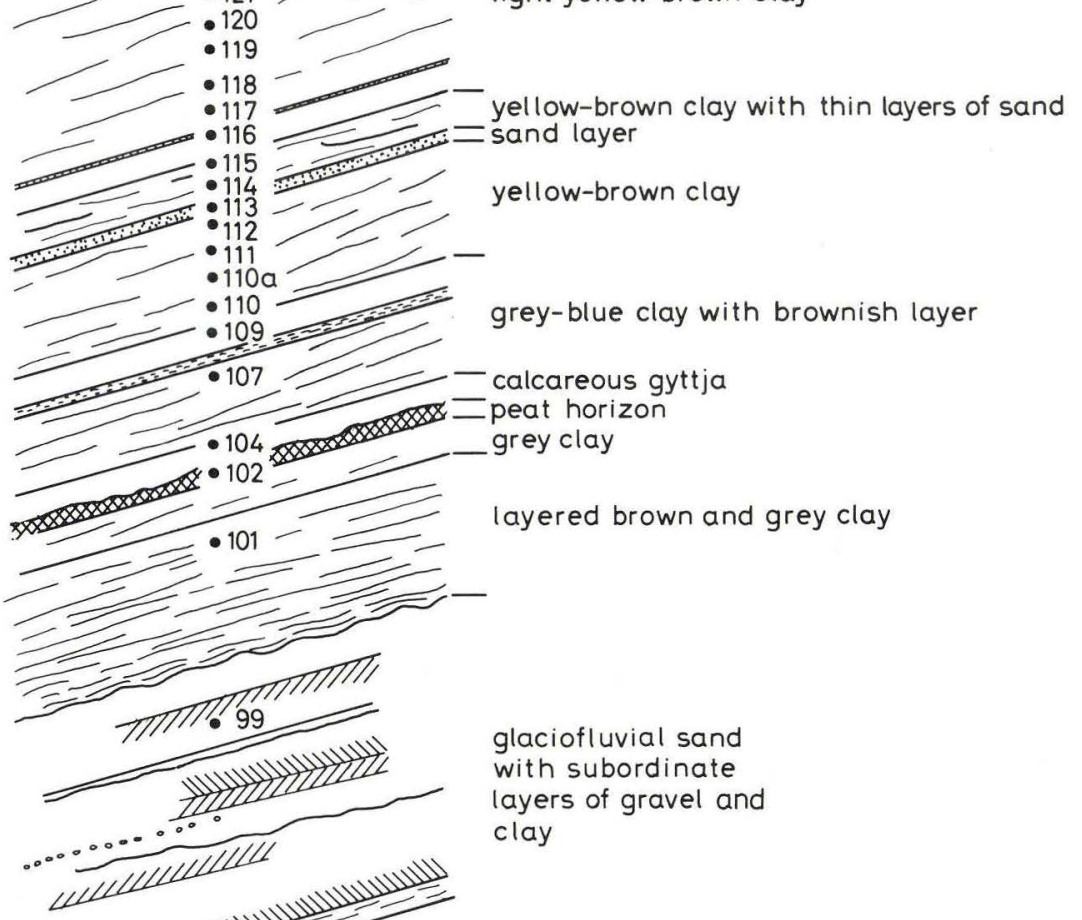

grey-blue clay with brownish layer

yellow-brown clay

glaciofluvial sand

with subordinate

layers of gravel and

clay

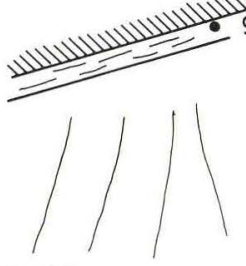

98

$8=00^{\circ}$

layered brown and grey clay

Fig. 2. Profile No. I Scale 1:100. The numbers indicate investigated samples from this profile. 
very thin layers of sand are found in the clay. It is followed by a light yellow-brown clay, also containing shell fragments (samples 116 to 123). This clay makes up the rest of the profile, except for a top cover of clayey till. The clay containing fragments of marine molluscs is the Cyprina Clay.

The stratification of the marine strata strikes $130^{\circ}$ and dips $26^{\circ}$ to the southwest. No faults are seen in this profile, but some are found in the Eemian deposits of the cliff at several places to the north of profile No. I. The faults were probably formed when the strata were displaced during the Weichsel Glaciation.

\section{Profile No. II}

The second profile, No. II, is located 670 m north of "Fiskerhuset'" and includes a glacially displaced slice of Eemian sediments. According to the survey of Dr. Sigurd Hansen, this slice is the one investigated by Gottsche in 1904. The whole Eemian sequence seems to be represented here. The profile is illustrated in Fig. 3. The upper limit of the Tapes Sand is situated $12.5 \mathrm{~m}$ above sea level. The cliff strikes north-south and the stratification in the profile dips $20^{\circ}$ to the south.

The Eemian sequence is underlain by a layered light greyish sand with a rusty horizon conforming to the stratification of the sand $30 \mathrm{~cm}$ below its top (samples 201 and 202). The Eemian deposits start with $20 \mathrm{~cm}$ of calcareous gyttja, white in the lower part and grey in the upper part (sample 204). This alters gradually over a few cm into a bluish clay, which contains shells and is a little sandy in the lowest part (samples 205 and 206). $40 \mathrm{~cm}$ above the calcareous gyttja there is a mussel bed containing many shellfragments, mostly Mytilus edulis (sample 207). The superposing dark, bluish, very coherent, sticky clay is the so-called Cyprina Clay, in which many shells of Arctica islandica are seen (samples 208 to 225). The two shell-halves are always found together, but chrused probably because of ice-pressure. This clay has a faint stratification, and because of that a fault can be seen. The fault is oblique to the stratification and situated $1 \mathrm{~m}$ above the mussel bed. This is not found above the fault, and therefore the vertical displacement must be less than $1 \mathrm{~m}$. I have not been able to identify additional faults in this profile, though Madsen et al. (1908, p. 84) spoke of two overthrusts in Gottsche's profile. In the upper part the colour of the Cyprina Clay gradually changes to light grey-blue, owing to an increasing content of silt, which also makes the clay less coherent (samples 221 to 225).

After a gradual transition of a few cm (sample 227) the so-called Tapes 


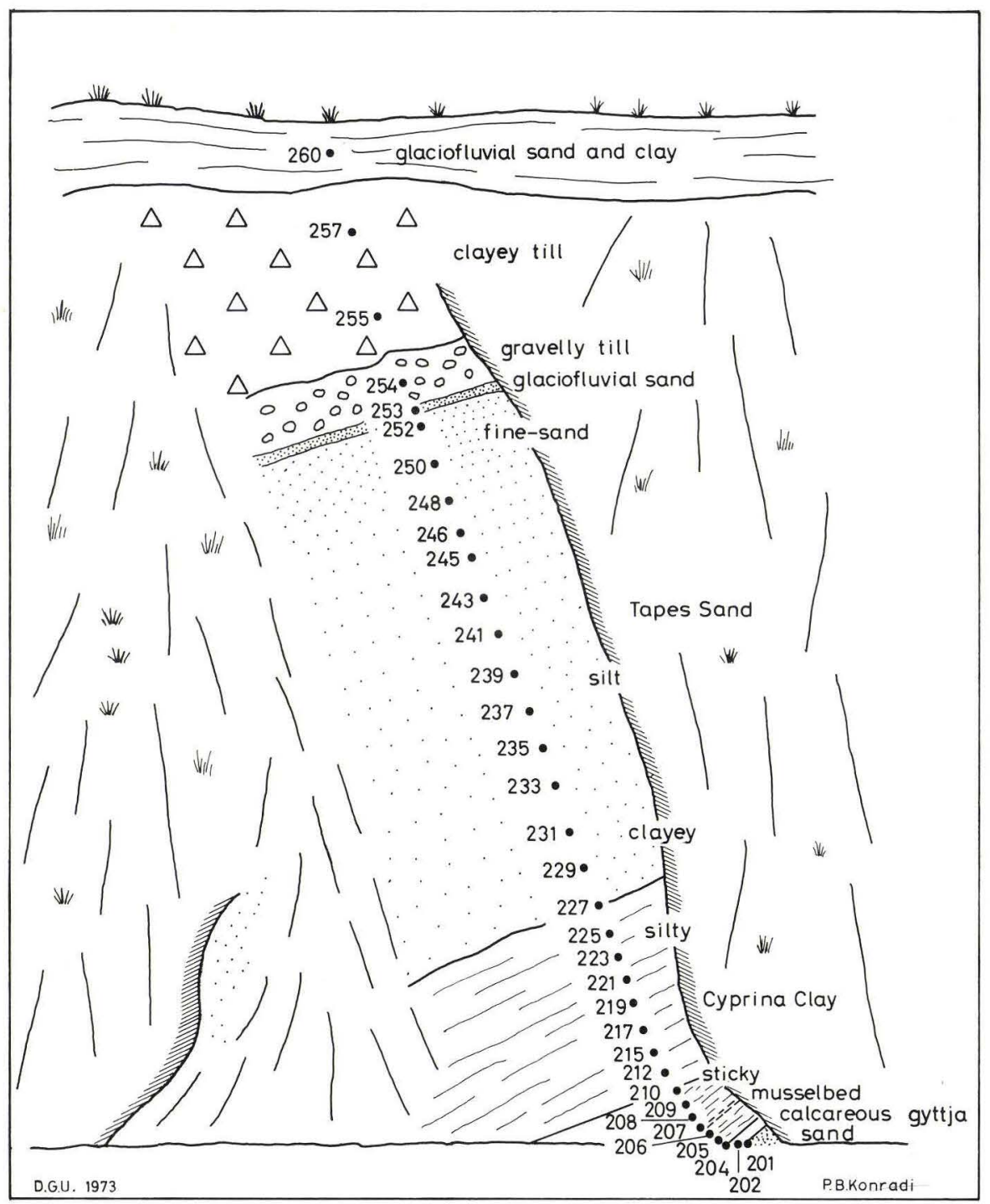

Fig. 3. Profile No. II. Scale 1:150. The numbers indicate investigated samples from this profile.

Sand follows (samples 229 to 252). It has a yellowish colour and in reality is made up mostly of silt, in the lower part also of some clay, which makes it fairly hard. The uppermost $2.5 \mathrm{~m}$ of the Tapes Sand are made up of whitish fine sand (samples 246 to 252). Everywhere in the Tapes Sand shells 
of molluscs are found, which are never crushed. Even an $8 \mathrm{~cm}$ big shell of Ostrea edulis was complete.

The Tapes Sand is overlain by $10-20 \mathrm{~cm}$ of white glaciofluvial sand followed by $1 \mathrm{~m}$ of gravelly till, and $3 \mathrm{~m}$ of clayey till. The top of the cliff is formed by $1-2 \mathrm{~m}$ of horizontally layered glaciofluvial sand with clay beds. 


\section{Methods}

\section{Collection of samples}

In profile No. I, 22 samples, as indicated in Fig. 2, have been investigated. From the non-marine part one representative sample has been taken from each lithological unit. From the marine sequence samples have been taken with a spacing af $20-30 \mathrm{~cm}$. Each sample represents a maximum thickness of $5 \mathrm{~cm}$.

In profile No. II, 35 samples, as indicated in Fig. 3, have been investigated. Again every non-marine unit was represented by one sample. In the Cyprina Clay the samples with numbers lower than 210 have been taken with a spacing of $20-25 \mathrm{~cm}$. Samples with higher numbers have been taken with a spacing of $50 \mathrm{~cm}$. In the Tapes Sand there were $70 \mathrm{~cm}$ between the samples. Each sample represents a maximum thickness of $5 \mathrm{~cm}$.

\section{Working up and plotting}

Disintegration, washing and separation of the samples and examination of the fossils under the microscope have been done according to the methods mentioned by Feyling-Hanssen (1964, p. 43). Furthermore, the fraction less than $0.1 \mathrm{~mm}$ was washed through a $0.063 \mathrm{~mm}$ sieve, to check what was washed through the $0.1 \mathrm{~mm}$ sieve.

The frequency distributions of the foraminifera in the $1.0-0.1 \mathrm{~mm}$ fraction of the samples from the two profiles are indicated in the range charts of tables 1 and 2 . In these the foraminifera identified as not primarily belonging to the marine Eemian deposits are listed under Prequaternary species. In every sample at least 300 specimens were counted if possible, and the total number estimated by extrapolation (Phleger 1960). The species diversity, as defined by Walton (1964), is indicated for the marine Eemian strata, on the basis of the foraminifera belonging to the Eemian deposits. A cumulative grain-size distribution curve has been worked out for $1.0 \mathrm{~mm}, 0.1 \mathrm{~mm}$ and $0.063 \mathrm{~mm}$, based on the weight of the different fractions. The occurrence in the whole sample of molluscs, ostracods, diatoms, sponge-needles and plant remains is also mentioned. 


\section{Results}

\section{Prerequisites}

In order to use a fauna in the interpretation of the ecological and stratigraphical conditions of a deposit, the fauna must belong - be primary - in the deposit.

A fossil foraminiferal assemblage can have been exposed to secondary alterations after deposition.

The foraminifera which I believe to belong to the Eemian deposits are found in a good state of preservation. The calcareous species are mostly found as unbroken hyaline tests without secondary calcareous deposits. Corrosion of the tests is found only to a small degree and in parts of the population. The calcareous foraminifera are therefore considered not to have undergone any secondary alterations. Arenaceous species are not found in the investigated deposits. It is impossible to decide whether this is due to secondary alterations in the sediment, the treatment of the samples in laboratory, or a lack of arenaceous species in these deposits. Van Voorthuysen (1957) did not find any arenaceous species in the Eemian deposits of the Netherlands. He believed that this was due to primary ecological factors. Lafrenz (1963) agreed in this. Buch (1955) found only one arenaceous specimen in Eemian deposits and only one broken specimen in Holsteinian interglacial deposits. Woszidlo (1962) did not find any in the Holsteinian deposits. This is remarkable, because arenaceous species are common today in the Baltic Sea (Brodniewicz 1965, Lutze 1965) and along the North Sea coast of the Netherlands and northern Germany (van Voorthuysen 1960, Haake 1962) in sediments similar to the interglacial sediments. Brodniewicz (1965) showed in laboratory experiments that arenaceous foraminifera would probably not be preserved in a sediment as found in the recent Baltic Sea, because of destruction in the sediment. She assumed that this was the reason for the lack of arenaceous foraminifera in interglacial deposits.

A fossil foraminiferal fauna is allochthonous, consisting partly of the species which lived in the place, and partly of species washed into the place of deposition. 
By investigating the content of foraminifera in the glaciofluvial deposits and the freshwater clay underlying the marine sequence, it is possible to check the derived foraminifera which have been washed out into the Eemian sea from the surrounding glacial deposits. The foraminifera in a sample represent the thanatocoenosis, which may be different from the biocoenosis (Lutze 1965). It is possible that some of the species occurring at low frequencies in the Eemian deposits were carried to the place of deposition by currents in the sea. This is probably the case for the two specimens of Elphidium margaritaceum, which have a broken test. It may also be the case for Elphidium bartletti, which often occurs with an opaque, milky-white test and the last chamber missing. It is perhaps also the case for Protelphidium magellanicum, of which a few specimens are usually found in the samples. On the other hand this species is always found with a hyaline test and without secondary alterations, and therefore may be primary to the deposit.

\section{Derived foraminifera}

The foraminifera found in the strata underlying the marine Eemian deposits are probably derived from the Prequaternary substrata mostly Tertiary, but also Cretaceous. These species are recognized by often having secondarily deposited material in the sutures and showing signs of transportation, for example, the lack of one or more chambers, or projecting points or spines. The Cretaceous species are mostly opaque white. Many of these derived species are only identified to genus, because of a poor state of preservation. The derived foraminifera are not listed in the systematic part.

The following foraminiferal species are found in the Saalian glaciofluvial deposits and Eemian freshwater deposits underlying the marine Eemian sequence. When they occur in the Eemian strata, they are regarded as being derived specimens redeposited into the Eemian sediment:

Amphicoryna sp.

Bolivina antiqua d'Orbigny 1846

Bolivina cf. robusta Brady 1881 ?

Bolivina sp.

Bulimina cf. buchiana d'Orbigny 1846

Bulimina cf. elongata d'Orbigny 1846

Bulimina inflata Seguenza 1862

Bulimina marginata d'Orbigny 1826
Bulimina trigonalis ten Dam 1944

Bulimina sp.

Buliminella parvula Brotzen 1948

Cassidulina sp.

Cibicides sp.

Dentalina communis (d'Orbigny 1826)

Dentalina sp.

Eponides sp. 
Eouvigerina sp.

Fissurina bicarinata Terquem 1882

Fissurina sp.

Globigerina bulloides d'Orbigny 1826

Globigerina cretacea d'Orbigny 1840

Globulina gibba (d'Orbigny 1826)

Guttulina sp.

Gyroidina cf. soldanii d'Orbigny 1826

Hastigerina aequilateralis (Brady 1879)

Heterohelix striata (Ehrenberg 1840)

Lagena hispidula Cushman 1913

Lagena striata (d'Orbigny 1839)

Lagena sulcata (Walker \& Jacob 1798)

Lenticulina sp.
Nodosaria pyrula d'Orbigny 1826

Nodosaria sp.

Oolina globosa (Montague 1803)

Oolina hexagona (Williamson 1848)

Pullenia quinqueloba (Reuss 1851)

Pyrgo sp.

Sphaeroidina sp.

Trifarina angulosa (Williamson 1858)

Trifarina cuneata (Brotzen 1948)?

Uvigerina peregrina Cushman 1923

Uvigerina tenuipustulata van Voorthuysen 1950

Virgulina sp.

\section{Environment}

The marine deposits show varying composition of the sediments. The Cyprina Clay is mainly clay, containing some silt in the upper part. The Tapes Sand consists mostly of silt, in the lower part with some clay, and only the uppermost few metres are fine sand.

In connection with the change in the sediment from clay via silt to fine sand there is also a change in the fauna. This is seen in the frequencies of Nonion depressula, Elphidium articulatum, E. cuvillieri, E. excavatum var. a, Protelphidium anglicum, $P$. dittmeri, $P$. niveum, $P$. orbiculare and Ammonia batavus. The species found most frequently in the sandy sediment e.g. Nonion depressula, Elphidium articulatum, Protelphidium anglicum and Ammonia batavus are characteristic of marshy areas with shallow water (van Voorthuysen 1960, Haake 1962). Because of this, the change in the sediment is considered to be caused by a decrease in the water depth. This corresponds to the fact that grain size normally increases with decreasing water depth, so that the shallowest water has the coarsest sediments, because it is exposed to the highest wave-activity, leading to frequent redeposition. Protelphidium dittmeri seems to tolerate the conditions in the fine sand, whereas Elphidium excavatum var. a prefers the silty sediment and Protelphidium niveum and $P$. orbiculare belong to clay bottom with more quiet conditions.

The change in the sediment is also followed by a change in the number of foraminifera. The Cyprina Clay mostly contains more than 30,000 specimens in $100 \mathrm{~g}$ of dry sediment, whereas the Tapes Sand usually has less than 10,000 specimens in $100 \mathrm{~g}$ of dry sediment. This decrease may be owing to two main reasons. When the Tapes Sand was deposited, either the 
sedimentation rate was higher, or the environment was less favourable for the foraminifera, because of smaller amounts of food and frequent redeposition.

The number of Prequaternary species also increases with the grain size. These species probably came from surrounding Saalian glacial deposits, indicating that the coarser sediment originated from weathered glacial deposits such as coastal cliffs. This may also be the reason for the change in colour from the bluish Cyprina Clay to the yellowish Tapes Sand. Furthermore this indicates that the deposition took place relatively close to the coast.

A special change in the sediment is found in the layer of sand in profile No. I, sample 113. The fauna in this is quite different from that of the surrounding Cyprina Clay, and is dominated by Elphidium gunteri (29\%) and Elphidium articulatum (28\%). Today Elphidium gunteri is found in marshy areas and withstands salinities as low as $4 \%$ (van Voorthuysen 1960, Todd \& Low 1961). Elphidium articulatum is found today in sandy marsh areas and lagoons with salinities as low as 2-4\%o (van Voorthuysen 1960, Lutze 1968). Therefore this sand layer is believed not to belong to the facies of the Cyprina Clay, but to have been redeposited into this position from areas with shallow and brackish water close to the coast.

In Recent many of the foraminifera are found mostly in shallower water: Nonion depressula, Elphidium articulatum, E. cuvillieri, E. excavatum, Protelphidium anglicum and Ammonia batavus. Two species are found only at depths of less than $15 \mathrm{~m}$ (Lutze 1965): Elphidium excavatum var. a and Protelphidium albiumbilicatum. Parker (1948) stated that Quinqueloculina seminulum is normally found at depths down to $52 \mathrm{~m}$, and Haake (1962) found it in marshy areas with a salinity of $30 \%$ on the German North Sea coast. Lutze (1965) found this species in the Baltic Sea only at depths exeeding $20 \mathrm{~m}$, where the salinity was higher than $20 \%$. This indicates that the Cyprina Clay of the samples 210-212, which had the highest frequency of Quinqueloculina seminulum and no Elphidium excavatum var. a, was deposited at the greatest water depth, probably exeeding $15 \mathrm{~m}$. The rest of the sequence was deposited at lower depth.

All the foraminifera tolerate brackish water: Quinqueloculina seminulum must have a salinity of above $20 \%$ (Lutze 1965), Ammonia batavus must have more than $15 \%$ under temperatures as in the recent Baltic Sea (Lutze 1965), but can survive $4 \%$ with temperatures as high as in the estuary of the river Eems today (van Voorthuysen 1960), Elphidium articulatum prefers more than $13 \%$, but can survive $4 \%$ (van Voorthuysen 1960) and Protelphidium albiumbilicatum even withstands salinities as low as $3.5 \%$ (Rottgardt 1952). The salinity of the Eemian sea in the former Baltic basin 
was therefore more than $20 \%$ when the Cyprina Clay was deposited, and more than $4 \%$, but lower than $30 \%$ and falling to under $20 \%$ when the Tapes Sand was deposited. At this time the occurrence of Ammonia batavus indicates that either temperature or salinity or both of them were higher than in the upper layers of the recent Baltic Sea. This species was not found here where the salinity was between 13 and $19 \%$ and summer temperatures reached $20^{\circ}$ (Lutze 1965).

The fauna contains two elements, which in Recent have different distributions. Elphidium bartletti and Protelphidium orbiculare are like Buccella frigida found today in arctic regions. The latter is also found in boreoarctic regions. Nonion depressula, Elphidium articulatum, E. cuvillieri and E. gunteri are mostly found in southern-boreal to lusitanian regions. The same may be the case for Guttulina austriaca. The remaining species either have a wide distribution or are found in boreal regions. Both faunal elements constitute a significant part of the fauna and are found side by side in the deposit. The arctic Protelphidium orbiculare decreases in frequency upwards in the profile, while the other "cold" species, Buccella frigida, increases. These changes may have been related to the change in grain size. This may also be the reason for the changes in the occurrence of the "warm" species. The changes may however also indicate an increase in temperature in the lower part of the Cyprina Clay.

It is difficult to explain these two different faunal elements from the recent distribution patterns of the species. It is possible that our knowledge of their distribution is too limited and that further investigations on recent faunas will show a wider distribution pattern. Another possibility is that the Eemian sea provided special ecological conditions which allowed the two faunal elements to live side by side.

There are no signs of a decrease in temperature in the upper part of the strata.

Walton (1964) defined faunal diversity as the number of ranked species of a foraminiferal population whose cumulative percentages constitute $95 \%$ of the total fauna. Already in 1960 Walton stated that the faunal diversity was inversely proportional to the variability of the environment, which becomes more variable under marginal marine conditions or close to a coast. Gibson (1966) used the term species diversity, which was little different from faunal diversity, and found that this too was inversely proportional to the variability of the environment. He stated that low diversity was found in regions with high wave and current activity or with unstable conditions of salinity, temperature and turbidity, as is typical in coastal areas.

The faunal diversity of the Eemian fauna is low, varying from 1 to 10 , 
mostly 6 to 9 . This means that the fauna of the Eemian deposits at Stensigmose occurred in marginal areas of the Eemian sea, where the environment was changeable and reached extreme conditions. For this reason the results of the investigation are limited to sediments deposited close to the coast, and cannot be generally valid for the whole sea of the Eem Interglacial.

\section{Stratigraphy}

From the above-mentioned considerations the following conclusions can be drawn concerning the formation of the investigated deposits.

The glaciofluvial sand, starting the strata in profile No. I, was probably formed in the Saale Glaciation. The river depositing these sediments suddenly changed its course, and the riverbed became a lake, in which the layered clay was deposited. The cause for the layering is unknown, but gradually diminished, and the layered clay gradually turned into the grey clay. Both of these deposits were probably formed late in the Saale Glaciation. After this the basin was dry. After a rise in the groundwater level the peat was formed. Later the water level rose again, and a lake was formed, in which the calcareous gyttja was deposited early in the Eem Interglacial, before the content of lime of the surrounding ground was leached out.

The development at profile No. II has a shorter story. The basal layered sand is probably Saalian glaciofluvial sand. The rusty horizon might have been formed by percolating water, while the deposit was above groundwater level for some time (Late Saalian or Early Eemian). Later the water level rose, and at once a lake was formed, in which the calcareous gyttja was deposited in the early Eem Interglacial.

After this, the development at the two profiles was parallel. Only the thicknesses are different, profile No. I being thicker. A comparison of the two profiles in tables 1 and 2 shows that profile No. I represents the lower part of profile No. II up to sample 219 or 221.

Above the calcareous gyttja a clay was deposited. Its lower part lacks foraminifera, and therefore was deposited in a freshwater lake. Higher up in the profile foraminifera start appearing in the clay, indicating that the sea penetrated into the basin. This water initially had a very low salinity permitting only the species Protelphidium albiumbilicatum to thrive. In the samples 109, 110 and 206 it makes up almost $100 \%$ of the fauna. Next in profile II there was a musselbed of Mytilus edulis, where only the two foraminiferal species Protelphidium albiumbilicatum and P. orbiculare lived. This is the first sign of increasing salinity. In the following samples 
a fauna with several species occurs, indicating higher salinity. This was presumably caused by an enlarging of the connection to the open sea. As the fauna consists of more calcareous species than the fauna in the present Baltic Sea, the Eemian sea in the Baltic area must have had a better connection to the open sea than the Baltic Sea today.

The fauna of the Cyprina Clay was dominated by the species Elphidium excavatum, Protelphidium niveum, P. orbiculare and Buccella frigida, while the less frequent species were Quinqueloculina seminulum, Guttulina austriaca, Elphidium articulatum, E. incertum, Protelphidium albiumbilicatum, P. anglicum, P. dittmeri, P. magellanicum and Ammonia batavus. The strata containing Quinqueloculina seminulum were deposited at the greatest water depth. In profile No. I this species did not occur, indicating that this profile was situated at a lower water depth closer to the coast, as also indicated by the greater thicknesses of the strata and the sand layer. The occurrence of the probably "warm" species Guttulina austriaca and at the same time a strong decrease in frequency of the arctic species Protelphidium orbiculare to a non-dominant species indicate a rise in temperature in the lower part of the Cyprina Clay. In the upper part of the Cyprina Clay, Quinqueloculina seminulum disappeared and new species appeared. These were Nonion depressula, which was quite sparse, and Elphidium excavatum var. a, which soon became frequent. This indicates that the water depth was again lowered, perhaps by a filling up of the basin. This agrees with the simultaneous change in the sediment to a more silty one. A result of this could be the sparse occurrence of Elphidium bartletti and the decrease in frequency of Protelphidium niveum, which ceased to be a dominant species.

The Tapes Sand was dominated by Elphidium excavatum and Buccella frigida. The frequencies of Elphidium articulatum, E. incertum, Protelphidium niveum and $P$. orbiculare changed irregularly. A single, probably redeposited, specimen of Elphidium margaritaceum was seen in two samples. The Prequaternary species now always made up at least $1 \%$ of the fauna. In the upper part of the silty Tapes Sand a new species appeared: Elphidium cuvillieri, whereas the frequency of Elphidium excavatum var. a decreased and Elphidium bartletti disappeared.

The uppermost fine sandy Tapes Sand showed a pronounced change in the fauna. Buccella frigida and Elphidium excavatum still dominated, but at lower frequencies. The frequency of the shallow water species Elphidium articulatum increased fast and reached that of the above-mentioned two species. The same applies to the number of Prequaternary species. There was also a smaller increase of Elphidium cuvillieri, E. gunteri, Protelphidium dittmeri and Ammonia batavus. Most of these species are typical of 
the shallowest water. Other species decreased in frequency or disappeared: Elphidium excavatum var. a, E. incertum, Protelphidium albiumbilicatum, $P$. niveum and $P$. orbiculare. These faunal changes and the coarsest grain size of the marine sequence, indicate the shallowest depth of deposition.

The overlying glaciofluvial sand and gravelly till from the Weichselian Glaciation contained a few foraminifera, of which two-thirds belong to the Eemian fauna. Thus the sediments of these two units partially originated from the Eemian deposits. The superposing clayey till contained several foraminifera, but only 5-20\% originated from the Eemian fauna. The horizontally layered glaciofluvial sand at the top of the cliff contained many foraminifera, of which two-thirds came from the Eemian fauna. This sand was deposited after the dislocation of the interglacial strata, and it seems reasonable that the sand originated partially by erosion from the Eemian deposits. The stream depositing the glaciofluvial sand probably came from the glacier that formed the moraines in which the cliff is situated. This glacier must have been the last one occurring at this locality, presumably in the last part of the Weichsel Glaciation.

\section{Comparisons}

Van Voorthuysen (1957) stated that the climate of the Eem Interglacial in the Netherlands corresponded with the climate of the southern North Sea area today or was a little warmer, but the temperature was certainly not lusitanian or mediterranean. Unlike the Eemian deposits investigated by van Voorthuysen, the samples from Stensigmose contained the species Guttulina austriaca, probably owing to differences in the environment. They also contained the arctic species Elphidium bartletti and Protelphidium orbiculare, the latter at rather high frequencies. This may be due to the more northerly position of the Danish deposit.

Lafrenz (1963) came to a similar conclusion and also found a rise in temperature in the lower part of the deposits. He gave an interglacial age to several species which I think were derived from the Prequaternary substratum. My reason for this is that these species were also found in the Saalian glaciofluvial deposits and Eemian freshwater deposits underlying the marine Eemian sequence.

By comparing the profile given by Lafrenz (1963, table 7) from Stensigmose with my range charts, tables 1 and 2 , I must conclude that the strata investigated by him only correspond to the upper part of my profile No. II, i.e. the Tapes Sand. The fauna of Lafrenz' Cyprinenton which he considered to be Unteres Eem (Lower Eemian), corresponds to the one in my 
silty Tapes Sand. The fauna in his Tapes-Sand from the Oberes Eem (Upper Eemian) corresponds to the fauna in my fine sandy Tapes Sand. Lafrenz has therefore not investigated deposits corresponding to the Cyprina Clay at Stensigmose.

Nordmann (in Madsen et al. 1908, p. 246 ff.) also found an element of "cold" species in the mollusc fauna e.g. Arctica islandica, and discussed the possibility of a relict fauna. On the basis of the occurrence of several lusitanian species Nordmann (in Madsen et al. 1908, p. 247; 1928, p. 51) concluded that the Eemian mollusc fauna in Denmark should be compared with that of the Channel or western France today. This differs from the above-mentioned result based on the foraminifera. There can be several reasons for this. The knowledge of the recent distribution of the foraminifera or of the molluses can be too limited. It is also possible that the recent distribution pattern, both for the molluses and for the foraminifera, is different from the distribution in the Eem Interglacial because of different ecological conditions.

The Eemian deposit at Strandegaards Dyrehave (Petersen \& Konradi 1974) was found in glacially displaced slices. It was referred to the Eemian because its foraminifera fauna included the characteristic Eemian species and combinations of species. The fauna was developed in several facies and also contained species not known from Stensigmose. The marine sediment at Strandegaards Dyrehave was therefore probably deposited under slightly different ecological conditions.

The lower part of the Skærumhede II boring was referred to the Eemian (Konradi in Bahnson et al. 1974) mainly on the basis of the ecological indications of the boreo-lusitanian and boreal foraminifera assemblages. The fauna also contained some of the characteristic "warm" Eemian species, but it also included other species of importance and it was different from the one at Stensigmose. The interglacial foraminifera fauna at Skærumhede probably represented a more open sea facies. Furthermore the sequence of the Skærumhede II boring was from the end of the interglacial, whereas the deposits from southern Jutland and northern Germany were from the beginning and the optimum of the interglacial. 


\section{Systematic part}

The foraminifera are arranged systematically in accordance with the classification of Pokorný (1963), with the addition of the genera Buccella Andersen 1952 and Protelphidium Haynes 1956, which are identified after Loeblich \& Tappan (1964).

The determination of the foraminifera is based partly on the Catalogue of Foraminifera (Ellis \& Messina 1964) and partly on papers dealing with deposits similar to those investigated.

Nineteen species belonging to six families and originating in the interglacial deposits are treated. Instead of a description of the species, a previous description is referred to which is in agreement with the specimen under consideration. Differences from this description are mentioned. A representative specimen of most of the species has been investigated by scanning electron microscope (SEM) for detailed studies of the morphology. Two dimensions have been measured of at least ten representative specimens of each of the treated species. The dimensions are defined in the following way: For planispiral and trochospiral forms greatest diameter is the largest measure at right angles to the axis of coiling, and thickness is the largest measure parallel to this axis. For the other species length is the measure from the apertural end of the test to the opposite end, whereas breadth is the largest measure at right angles to this one. For these species the thickness is also measured. This is the smallest measure at right angles to the length. The occurrence of the species under consideration in the investigated strata is given. Their distribution both stratigraphic and Recent, is mentioned on the basis of the literature. Under remarks, papers giving useful information on the species are referred to, and characters of systematic value are discussed.

Order Foraminifera d'Orbigny 1826

Superfamily Miliolidea Ehrenberg 1839

Family Miliolidae Ehrenberg 1839

Genus Quinqueloculina d'Orbigny 1826

Quinqueloculina seminulum (Linné 1758)

Pl. 1, fig. 1. 
1758: Serpula seminulum Linné, p. 786, pl. 2, fig. 1.

1929: Quinqueloculina seminulum (Linnaeus) - Cushman, p. 24, pl. 2, figs. 1, 2.

1948: Quinqueloculina seminula (Linné) - Parker, p. 221, pl. 1, fig. 3.

1962: Quinqueloculina seminula (Linnaeus) - Haake, p. 31, pl. 1, figs. 13, 14.

1964: Quinqueloculina seminulum (Linné) - Feyling-Hanssen, p. 251, pl. 6, fig. 1.

The specimens from the Eemian deposit at Stensigmose are in agreement with the description given by Cushman (1929).

Measurements: Length: $\quad 0.40-1.35 \mathrm{~mm}$, average $0.90 \mathrm{~mm}$.

Breadth: $\quad 0.30-0.90 \mathrm{~mm}$, average $0.63 \mathrm{~mm}$.

Thickness: $\quad 0.20-0.70 \mathrm{~mm}$, average $0.43 \mathrm{~mm}$.

Occurrence: This species was found only in the Cyprina Clay of profile No. II in the samples 209-223 and reached a maximum frequency of $3 \%$.

Distribution: Ten Dam \& Reinhold (1941) mentioned the species from the Pliocene, and van Voorthuysen (1950) recorded it in the oldest Pleistocene deposits in the Netherlands. A few specimens of the species were found in Holsteinian deposits by Buch (1955), Woszidlo (1962) and Wiegank (1972). He also recorded it from the Rügen Interstadial. Lafrenz (1963) found the species in Eemian deposits. It was found in Late Weichselian and Flandrian deposits by Feyling-Hanssen (1964) and Michelsen (1967). The recent distribution of this species is very wide (Feyling-Hanssen 1964).

Remarks: The species was found by Parker $(1948,1952)$ as a common one at depths down to $52 \mathrm{~m}$ with a salinity of 32-33\%. Todd \& Low (1961) recorded it as frequent in open sea areas, but not in protected bays and brackish ponds. Haake (1962) found the species in tidal flats, where the salinity was $30 \%$, whereas van Voorthuysen $(1951,1960)$ only found it secondarily in tidal flats with brackish water. This is in agreement with Feyling-Hanssen (1964) and Risdal (1964), who did not find the species in the shallowest water of the Oslofjord, where the salinity was lower than ca. $25 \%$. Lutze (1965) only found the species in the Baltic Sea at depths of more than $20 \mathrm{~m}$, where the salinity was higher than $20 \%$. This species therefore seems to demand a salinity of more than $20 \%$ and only to live in the shallowest water when the salinity reaches $30 \%$ or more.

The samples containing Quinqueloculina seminulum therefore represent those strata of profile No. II which are deposited at the greatest water depth.

Superfamily Nodosariidea Ehrenberg 1839

Family Polymorphinidae d'Orbigny 1839

Genus Guttulina d'Orbigny 1826

Guttulina austriaca d'Orbigny 1846

Pl. 1, fig. 4 . 
1846: Guttulina austriaca d'Orbigny. p. 223, pl. 12, figs. 23-25.

1930: Guttulina austriaca d'Orbigny - Cushman \& Ozawa, p. 29, pl. 4, figs. 3-5.

1963: Guttulina austriaca d'Orbigny - Lafrenz, p. 18, pl. 1, figs. 7, 8.

1972: Guttulina dawsoni Cushman \& Ozawa - Wiegank, p. 23, pl. 1, fig. 8.

The specimens from Stensigmose are in agreement with the description given by Cushman \& Ozawa (1930).

$$
\begin{array}{cl}
\text { Measurements: Length: } & 0.40-0.80 \mathrm{~mm} \text {, average } 0.55 \mathrm{~mm} \text {. } \\
\text { Breadth: } & 0.20-0.40 \mathrm{~mm} \text {, average } 0.27 \mathrm{~mm} \text {. } \\
\text { Thickness: } & 0.20-0.30 \mathrm{~mm} \text {, average } 0.23 \mathrm{~mm} \text {. }
\end{array}
$$

Occurrence: This species was found in the upper part of the Cyprina Clay and in the Tapes Sand. It reached a maximum frequency of $3 \%$ in sample 223 , but normally made up $1 \%$ or less of the fauna.

Distribution: According to Cushman \& Ozawa (1930) this species was found from the Eocene to the Recent. Lafrenz (1963) found it in Eemian deposits, and Feyling-Hanssen, Jørgensen, Knudsen \& Andersen (1971) found it in Weichselian deposits. Wiegank (1972) recorded a species called Guttulina dawsoni in Saalian interstadial deposits. His figure of the species (pl. 1, fig. 8) seems to agree with my Guttulina austriaca, and therefore this species is believed also to occur in the Rügen Interstadial.

Remarks: Lafrenz (1963) found the species in the Eemian strata of northern Germany, whereas van Voorthuysen (1957) did not find it in the Eemian of the Netherlands perhaps owing to differences in the environment.

In Recent, Cushman \& Ozawa (1930) only found the species in tropical and lusitanian waters. Feyling-Hanssen et al. (1971) stated that it had not been observed in Recent Arctic and Antarctic waters. The species may therefore belong to "warmer" areas.

Superfamily Buliminidea Jones 1875

Family Nonionidae Schultze 1854

Genus Nonion Montfort 1808

Nonion depressula (Walker \& Jacob 1798) emend. Murray 1965

Pl. 1, figs. 2-3; pl. 4, figs. 1-2.

1798: Nautilus depressulus Walker \& Jacob, p. 641, fig. 33.

1957: Nonion umbilicatulus (Walker \& Jacob, emend. Montagu) - van Voorthuysen, p. 29, pl. 23 , figs. $4 a$, b.

1962: Nonion umbilicatulum (Walker \& Jacob) - Haake, p. 41, pl. 3, figs. 3, 4.

1965b: Nonion depressulus (Walker \& Jacob) sensu stricto, emendated diagnosis Murray, p. 148 , pl. 25 , figs. 6,7 , pl. 26 , figs. 7,8 . 
The specimens from Stensigmose are in agreement with the emendated description by Murray (1965 b).

Measurements: Greatest diameter: $0.20-0.26 \mathrm{~mm}$, average $0.23 \mathrm{~mm}$.

Thickness: $0.08-0.11 \mathrm{~mm}$, average $0.09 \mathrm{~mm}$.

Number of chambers in the last whorl: 8-11, mostly 9.

Occurrence: This species was found only in profile No. II in the silty Cyprina Clay and in the Tapes Sand. It usually made up around $1 \%$ of the fauna, but could reach $4 \%$ as in sample 239.

Distribution: Van Voorthuysen (1957) stated that this species occurred first in the Eemian and today belonged to the southern part of the North Sea. Lafrenz (1963) also recorded it from the Eemian. Michelsen (1967) and Feyling-Hanssen et al. (1971) found the species in Weichselian and Flandrian deposits. In Recent it was found on the North Sea coasts of the Netherlands (van Voorthuysen 1951, 1960), Germany (Haake 1962) and Great Britain (Murray 1965 a).

Remarks: The species was not found in the Oslofjord (Feyling-Hanssen 1964, Risdal 1964) or in the Baltic Sea (Lutze 1965).

The species is therefore considered to belong to southern boreal regions.

Superfamily Rotaliidea Ehrenberg 1839

Family Discorbidae Cushman 1927

Genus Buccella Andersen 1952

Buccella frigida (Cushman 1922) emend. Andersen 1952

Pl. 1, figs. 5-6.

1922: Pulvinulina frigida Cushman, p. 12.

1952: Buccella frigida (Cushman) - Andersen, p. 144, figs. 4-6.

1957: Buccella frigida (Cushman) - van Voorthuysen, p. 33, pl. 24, figs. 15 a, b, c.

1963: Buccella frigida (Cushman) emend. Andersen - Lafrenz, p. 25, pl. 2, figs. 10-14.

The specimens from Stensigmose are in agreement with the description by Andersen (1952), except that some specimens may have developed a slit in the umbilical sutures by corrosion.

Measurements: Greatest diameter: $0.20-0.43 \mathrm{~mm}$, average $0.33 \mathrm{~mm}$.

Thickness: $0.10-0.23 \mathrm{~mm}$, average $0.17 \mathrm{~mm}$.

Number of chambers in the last whorl: $6-8$, mostly 7 .

Occurrence: This species was found in the Cyprina Clay and in the Tapes Sand. It usually made up more than $10 \%$ of the fauna, in the upper part of the Tapes Sand even more than $20 \%$, and reached a maximum of $36 \%$ in sample 245.

Distribution: Van Voorthuysen (1950) found the species in the oldest Pleistocene deposits of the Netherlands. It was rare in the Holsteinian de- 
posits investigated by Woszidlo (1962), Buch (1955) and Wiegank (1972), who also recorded it in deposits from the Rügen Interstadial and from the Eemian. Buch (1955), van Voorthuysen (1957) and Lafrenz (1963) found it in Eemian deposits. The species was recorded from Weichselian and Flandrian deposits by Feyling-Hanssen (1964), Michelsen (1967) and FeylingHanssen et al. (1971). In Recent, it was mainly found in arctic and boreoarctic waters (Cushman 1948, Andersen 1952, Phleger 1952, Loeblich \& Tappan 1953).

Remarks: Lafrenz (1963, p. 25) described a subspecies with some reservations. I have not been able to identify this in the samples from Stensigmose.

Family Elphidiidae Galloway 1933

Genus Elphidium Montfort 1808

Elphidium articulatum (d'Orbigny 1839)

P1. 1, figs. 7-8.

1839: Polystomella articulata d'Orbigny, p. 30, pl. 3, figs. 9, 10.

1858: Polystomella umbilicatula Walker - Williamson, p. 42, pl. 3, figs. $81,82$.

1875: Polystomella umbilicatula Walker - Terquem, p. 25, pl. 2, fig. 3.

1930: Elphidium excavatum (Terquem) - Cushman, p. 21, pl. 8, figs. 4-7.

1968: Cribrononion articulatum (d'Orbigny) - Lutze, p. 27, pl. 1, figs. 1, 2.

The specimens from Stensigmose are in agreement with the description given by Cushman (1930).

Measurements: Greatest diameter: $0.33-0.68 \mathrm{~mm}$, average $0.43 \mathrm{~mm}$.

Thickness: $0.15-0.24 \mathrm{~mm}$, average $0.19 \mathrm{~mm}$.

Number of chambers in the last whorl: 9-16, mostly 10 or 11.

Occurrence: This species was found in the Cyprina Clay and in the Tapes Sand with the highest frequency in the sandy sediments. Normally it made up less than $7 \%$ of the fauna, but in the sand layer of profile No. I it reached $28 \%$ and in the uppermost Tapes Sand $24 \%$.

Distribution: The species was recorded from the oldest Pleistocene of the Netherlands (van Voorthuysen 1950), from the Holsteinian (Buch 1955, Woszidlo 1962, Wiegank 1972), from the Rügen Interstadial (Wiegank 1972) and from the Eemian (van Voorthuysen 1957, Lafrenz 1963, Wiegank 1972). It was found in Weichselian and Flandrian deposits in Scandinavia (Hessland 1943, Feyling-Hanssen 1964, Michelsen 1967, Feyling-Hanssen et al. 1971) and in Flandrian deposits of Poland (Brodniewicz 1965). In Recent it was found in the North Sea (Williamson 1858, Terquem 1875, Cushman 1930, van Voorthuysen 1951, 1960, Jarke 1961, Haake 1962, Lévy, Mathieu, 
Momeni, Poignant, Rosset-Moulinier, Rouvillois \& Ubaldo 1969), in the Oslofjord (Risdal 1964) and in the Baltic Sea (Lutze 1965, 1968). It was recorded from the east coast of North America north of Cape Cod (Cushman 1944 ) and in the Long Island Sound - Buzzards Bay area (Parker 1952).

Remarks: Williamson (1858) classed this species with Walker's Polystomella umbilicatula. This misidentification was followed by Terquem (1875), Lévy et al. (1969), Feyling-Hanssen et al. (1971) and Wiegank (1972). Cushman (1930) by mistake used Terquem's name Elphidium excavatumfor the species. This error was repeated by many authors, among others: van Voorthuysen (1950, 1951, 1957, 1960), Parker (1952), Buch (1955), Jarke (1961), Haake (1962), Woszidlo (1962), Lafrenz (1963), Feyling-Hanssen (1964), Risdal (1964) and Michelsen (1967). Lutze (1965) pointed out Cushman's mistake and in 1968 classed the species with Cribrononion articulatum. Williamson (1858) remarked the similarity to d'Orbigny's Polystomella articulata, but also pointed out that d'Orbigny's figure of the latter had a cribrate aperture in contrast to his Elphidium umbilicatulum. J. Murray (personal communication) has pointed out that Elphidium articulatum has cribrate foramina in the septa between earlier chambers of the last whorl. It was probably this species which d'Orbigny figured.

All authors agree that the species was found in shallow water. Van Voorthuysen (1960) and Haake (1962) found it as one of the five dominating species in tidal areas. Lutze (1968) found it as the dominating species in a lagoon with a water depth of less than $1 \mathrm{~m}$ and with salinity as low as 2-8\%. Van Voorthuysen (1960) found it in areas with clear and quiet water with salinity as low as 3-4\%.

This species was not recorded from arctic areas.

The species seems to belong to the shallow water in boreal areas and to withstand low salinity.

Elphidium bartletti Cushman 1933

Pl. 1, figs. 9-12.

1933: Elphidium bartletti Cushman, p. 4, pl. 1, fig. 9.

1953: Elphidium bartletti Cushman - Loeblich \& Tappan, p. 96, pl. 18, figs. 10-14.

1963: Elphidium bartletti Cushman - Lafrenz, p. 27, pl. 2, figs. 21-23, pl. 3, figs. 1-4.

The specimens from Stensigmose are in agreement with the descriptions by Cushman (1933) and Loeblich \& Tappan (1953), except that the chamber walls are often milky-white and that the umbilical area and the sutural pores can be extended as a result of corrosion. This was also seen by Lafrenz (1963). 
Measurements: Greatest diameter: $0.40-0.55 \mathrm{~mm}$, average $0.46 \mathrm{~mm}$.

Thickness: $0.20-0.25 \mathrm{~mm}$, average $0.24 \mathrm{~mm}$.

Number of chambers in the last whorl: 7-9, mostly 9 .

Occurrence: The species was found only in profile No. II in the silty Cyprina Clay and silty Tapes Sand. Normally there were only a few specimens in each sample.

Distribution: This species was recorded from the Rügen Interstadial by Wiegank (1972). It was found in Eemian deposits of northern Germany by Lafrenz (1963), but not in the Eemian of the Netherlands (van Voorthuysen 1957). It occurred in Weichselian marine deposits (Feyling-Hanssen 1964, Feyling-Hanssen et al. 1971). In Recent, it was recorded in arctic areas by Cushman $(1933,1939,1948)$, by Tappan (1951), by Phleger (1952) and by Loeblich \& Tappan (1953). It was found at depths from 0 to about $100 \mathrm{~m}$.

The species is considered to belong to arctic areas.

Elphidium cuvillieri Lévy 1966.

Pl. 2, figs. 1-4; pl. 4, figs. 3-4.

1957: Elphidium sp. A van Voorthuysen, p. 31, pl. 23, figs. 10 a, b.

1963: Elphidium sp. A van Voorthuysen - Lafrenz, p. 33, pl. 4, figs. 12-14.

1966: Elphidium cuvillieri Lévy p. 5, pl. 1, fig. 6.

1969: Cribrononion cuvillieri (Lévy) - Lévy, Mathieu, Momeni, Poignant, Rosset-Moulinier, Rouvillois \& Ubaldo, p. 92, pl. 1, figs. 10, 11.

The specimens from Stensigmose are in agreement with the description of Lévy (1966) and that of Lafrenz (1963). Furthermore, the wall of the test has an optically radial structure. Often the sutural pore situated nearest to the umbilicus is a little bigger than the rest of the pores in the sutures and in the umbilical area, so that the umbilicus seems to be surrounded by a ring og pores.

Measurements: Greatest diameter: $0.31-0.39 \mathrm{~mm}$, average $0.33 \mathrm{~mm}$.

Thickness: $0.13-0.18 \mathrm{~mm}$, average $0.15 \mathrm{~mm}$.

Number of chambers in the last whorl: 8-10, mostly 9 or 10 .

Occurrence: This species was found only in the upper part of the Tapes Sand, especially in the most sandy sediment, where it reached a maximum frequency of $4 \%$ of the total fauna.

Distribution: The species was recorded from the Rügen Interstadial (Wiegank 1972). It was found in Eemian deposits of the Netherlands (van Voorthuysen 1957) and of northern Germany (Lafrenz 1963, Wiegank 1972). In Recent the species was found in the Mediterranean (Lévy 1966) and in the Channel (Lévy et al. 1969).

Remarks: Dr. van Voorthuysen has kindly sent me an assemblage-slide, 
which among others contained his Elphidium sp. A. This and his figures of this species (1957, pl. 23, fig. 10) are in agreement with the specimens of Elphidium cuvillieri found at Stensigmose. They agree with Lafrenz' (1963) description of Elphidium sp. A. They also resemble closely the figures of Elphidium cuvillieri given by Lévy et al. (1969, pl. 1, figs. 10 a, b, 11). I must therefore conclude that the species, to which van Voorthuysen (1957) gave the informal name Elphidium sp. A, is the one named Elphidium cuvillieri by Lévy (1966). He called it a littoral species belonging to brackish water.

As this species is not found today in the North Sea (van Voorthuysen 1960, Haake 1962) nor in the Baltic Sea (Lutze 1965) it seems reasonable to conclude that it belongs to lusitanian areas.

Elphidium excavatum (Terquem 1875)

Pl. 2, figs. 5-6; pl. 4, figs. 5-6.

1875: Polystomella excavata Terquem, p. 25, pl. 2, fig. 2.

1909: Polystomella striatopunctata (Fichtel \& Moll) var. Heron-Allen and Earland, p. 695, pl. 21 , fig. 2 .

1911: Polystomella striatopunctata (Fichtel \& Moll) var. selseyensis Heron-Allen \& Earland, p. 448.

1957: Elphidium selseyensis (Heron-Allen \& Earland) - van Voorthuysen, p. 31, pl. 23, figs. 9 a, b.

1962: Elphidium selseyense (Heron-Allen \& Earland) - Haake, p. 49, pl. 5, figs. 12-15, pl. 6, figs. 1-5.

1965: Elphidium clavatum Cushman - Brodniewicz, p. 210, text-fig. 32, pl. 10, figs. 1-8.

1965: Cribrononion excavatum (Terquem) - Lutze, p. 96, pl. 15, figs. 40, 41.

1969: Cribrononion excavatum (Terquem) - Lévy, Mathieu, Momeni, Poignant, RossetMoulinier, Rouvillois \& Ubaldo, p. 93, pl. 1, figs. 1, 2, 4.

? 1969: Cribrononion lidoense (Cushman) - Lévy, Mathieu, Momeni, Poignant, Rosset-Moulinier, Rouvillois \& Ubaldo, p. 94, pl. 1, fig. 9.

1972: Elphidium excavatum (Terquem) forma selseyensis (Heron-Allen \& Earland) - Feyling-Hanssen, p. 341, pl. 4, figs. 1-7, pl. 5, figs. 1-7.

The specimens from Stensigmose are in agreement with the description given by Haake (1962) and by Feyling-Hanssen (1972).

Measurements: Greatest diameter: $0.19-0.40 \mathrm{~mm}$, average 0.28.

Thickness: $0.10-0.20 \mathrm{~mm}$, average $0.15 \mathrm{~mm}$.

Number of chambers in the last whorl: 7-9, mostly 8 or 9.

Occurrence: This species was found in the Cyprina Clay and the Tapes Sand. Except for the basal strata of the Cyprina Clay the species always made up at least $20 \%$ of the fauna, often more than $40 \%$, and reached a maximum frequency of $62 \%$ in sample 120. This species was the most 
frequent in the marine Eemian strata at Stensigmose in all except six samples.

Distribution: The species was recorded from Eemian deposits by van Voorthuysen (1957) and Lafrenz (1963). In Recent it was found in the Channel (Heron-Allen \& Earland 1909), at the North Sea coast of France (Terquem 1875, Lévy et al. 1969), of the Netherlands (van Voorthuysen 1951, 1960) and of Germany (Brand 1941, Haake 1962) and in the Baltic Sea (Rottgard 1952, Brodniewicz 1965, Lutze 1965).

Remarks: As regards the taxonomy of this species I agree with Lutze (1965) and Lévy et al. (1969), who considered Terquem's name Polystomella excavata (1875) as the first name of this species. Haake (1962) stated that the species varied, showing all transitions from specimens with several knots in the umbilical area and adjacent parts of the sutures (extreme form 1) to specimens without any knots in the umbilicus (extreme form 2). This was agreed upon by Lutze (1965), who investigated topotypes from Dunkerque. Nevertheless Lévy et al. (1969) separated the specimens with several umbilical knots under the name Cribrononion lidoense, but admitted that intermediate forms existed between this species and their Cribrononion excavatum. I am therefore inclined to include the lidoense-form in the species Elphidium excavatum, perhaps as a geographical subspecies as intimated by Lutze (1965) and Feyling-Hansen (1972).

In the Baltic Sea, Brodniewicz (1965) found a species which she called Elphidium clavatum. Her description and figures are in agreement with Lutze's Elphidium excavatum (1965), and I will therefore include Brodniewicz's Elphidium clavatum in the species under consideration.

Lutze's (1965) Elphidium excavatum excavatum and E. excavatum clavatum both seem to fall within the range of Elphidium excavatum forma selseyensis of Feyling-Hanssen (1972). The specimens from Stensigmose seem to be in accordance with Lutze's (1965) Elphidium excavatum clavatum found in the recent Baltic Sea at depths greater than about $15 \mathrm{~m}$ and are mostly developed in the form with one umbilical knob, as also mentioned by Lafrenz (1963). Still, there seem to be transitions to Lutze's Elphidium excavatum excavatum. Specimens in agreement with this form are listed under the name Elphidium excavatum var. a in this paper.

Elphidium excavatum was found as a typical species in brackish water: van Voorthuysen (1960) stated that it preferred salinity higher than $14 \%$, but would survive as low as $4 \%$. Rottgardt (1952) and Lutze (1965) came to a similar result.

The species seems to belong to the shallow water and to tolerate low salinity. 
Elphidium excavatum (Terquem 1875) var. a

Pl. 2, figs. 7-8; pl. 4, figs. 7-8.

? 1965: Cribrononion excavatum excavatum (Terquem) -Lutze, p. 96, pl. 15, figs. 39 a, b.

Under this name are grouped specimens of Elphidium excavatum, which are developed as a rather compressed form. They agree with Lutze's (1965) Elphidium excavatum excavatum, except that they always have a clearly developed umbilical plug.

Measurements: Greatest diameter: $0.23-0.33 \mathrm{~mm}$, average $0.28 \mathrm{~mm}$.

Thickness: $0.10-0.13 \mathrm{~mm}$, average $0.12 \mathrm{~mm}$.

Number of chambers in the last whorl: 8-10, mostly 9 .

Occurrence: This form was found in the upper part of the Cyprina Clay and in the Tapes Sand. It reached a maximum frequency of $16 \%$ in sample 223 , but normally made up less than $10 \%$ of the fauna. In the fine sanded Tapes Sand the form was rare or even missing.

Remarks: This form was separated from Elphidium excavatum by the compressed shape and distinct umbilical plug. Transitional forms were however found. They are listed with Elphidium excavatum. The compressed form was rare in the sediments deposited at the lowest water depth, though Lutze (1965) stated that the form dominated in the shallow water. The ecological indication of this form is not quite clear, as also intimated by Haake (1967). Further investigations of recent specimens of Elphidium excavatum may explain the ecological indications of the different forms of the species.

Elphidium gunteri Cole 1931

Pl. 2, figs. 9-10.

1931: Elphidium gunteri Cole, p. 34, pl. 4, figs. 9, 10.

1957: Elphidium gunteri Cole - van Voorthuysen, p. 32, pl. 23, figs. 11 a, b.

1960: Elphidium gunteri Cole - van Voorthuysen, p. 255.

1961: Elphidium gunteri Cole - Todd \& Low, p. 19, pl. 2, fig. 10.

1962: Elphidium gunteri Cole - Haake, p. 48, pl. 5, figs. 3, 4.

The specimens from Stensigmose are in agreement with the description by Cole (1931), except that the umbilical knobs can be less developed or replaced by granular materials.

Measurements: Greatest diameter: $0.30-0.45 \mathrm{~mm}$, average $0.35 \mathrm{~mm}$.

Thickness: $0.19-0.25 \mathrm{~mm}$, average $0.22 \mathrm{~mm}$.

Number of chambers in the last whorl: 9-12, mostly 10 .

Occurrence: This species was found in the Cyprina Clay and in the Tapes Sand. Normally there were only a few specimens of the species in each 
sample; in the Tapes Sand its frequency was about $1 \%$, but in the sand layer of profile No. I (sample 113) the species made up $29 \%$ of the fauna.

Distribution: Cole (1931) found the species in Pliocene deposits from Florida. It was recorded from the Rügen Interstadial by Wiegank (1972). He also found it in the Eemian, like van Voorthuysen (1957) and Lafrenz (1963). In Recent it was found in tidal areas of the Netherlands (van Voorthuysen 1951, 1960) and Germany (Haake 1962), at the North Sea coast of France (Lévy et al. 1969) and in lagoons of southern France (Le Calvez \& Le Calvez 1951). It was recorded from the east coast of North America from North Carolina and New England (Cushman 1944), from Martha's Vineyard (Todd \& Low 1961) and from the Gulf of Mexico (Parker 1954).

Remarks: Van Voorthuysen (1960) found the species in silty sediments with salinity as low as 4-8\%. Haake (1962) found it as one of the five dominating species in tidal areas, occurring only in silty sediments. Le Calvez \& Le Clavez (1951) found it in sand or sandy mud in brackish water with a salinity of 15-30\%. Todd \& Low (1961) found that this species preferred "a marshy and brackish habitat". The species was not recorded from the Recent Oslofjord (Risdal 1964) or Baltic Sea (Lutze 1965).

This species probably belongs to southern boreal and lusitanian areas with lowered salinity and low water depth.

Elphidium incertum (Williamson 1858)

Pl. 2, figs. 11-12.

1858: Polystomella umbilicatula (Walker) var. incerta Williamson, p. 44, pl. 3, fig. 82 a.

1965: Cribrononion incertum (Williamson) - Lutze, p. 103, pl. 21, figs. 43, 44.

1966: Elphidium incertum (Williamson) - Buzas, p. 592, pl. 72, figs. 1-6.

The specimens from Stensigmose are in agreement with the descriptions by Williamson (1858) and by Buzas (1966), but they are often opaque white and bigger, as mentioned by Michelsen (1967). The sutures may be extended by corrosion, in some specimens so much so that the sutural bridges have disappeared.

Measurements: Greatest diameter: $0.38-0.73 \mathrm{~mm}$, average $0.54 \mathrm{~mm}$. Thickness: $0.15-0.33 \mathrm{~mm}$, average $0.23 \mathrm{~mm}$.

Number of chambers in the last whorl: 9-11, mostly 10 .

Occurrence: This species was found in the Cyprina Clay and in the Tapes Sand. Its frequency was normally less than $5 \%$, in a few samples higher, and in sample 246 it reached $23 \%$.

Distribution: The species was recorded from the oldest Pleistocene de- 
posits of the Netherlands (van Voorthuysen 1950), from the Holsteinian (Buch 1955, Woszidlo 1962, Wiegank 1972), from the Rügen Interstadial (Wiegank 1972) and from the Eemian of Schleswig-Holstein (Lafrenz 1963), whereas it did not occur in the Eemian deposits of the Netherlands (van Voorthuysen 1957). It was recorded in Weichselian and Flandrian deposits in Scandinavia (Hessland 1943, Michelsen 1967, Feyling-Hanssen et al. 1971). In Recent the species was found in the North Sea (Williamson 1858, van Voorthuysen 1951, Jarke 1961), in the Baltic Sea (Brodniewicz 1965, Lutze 1965) and in Long Island Sound (Buzas 1966).

Remarks: Loeblich \& Tappan (1953) pointed out that Cushman's and others' opinion of Elphidium incertum was not in agreement with that of Williamson (1858), as they included specimens with an umbilical plug (Cushman, 1939, pl. 15, figs. 22-24). Buzas (1966) explained the relationships and showed that Elphidium incertum after Williamson had an optical granular wall structure, whereas Elphidium incertum in Cushman's opinion had an optical radiate wall structure and was identical with or a modification of Elphidium clavatum Cushman. Authors following Cushman's opinion were among others Nørvang (1945), Cushman (1948), Parker (1952), Phleger (1952), who spoke of Elphidium incertum \& variants, and FeylingHanssen (1964). The figures given by Cushman (1948) and Phleger (1952) indicated that they also found Williamson's Elphidium incertum. Therefore this species was also found in arctic areas. Williamson (1858) and van Voorthuysen (1951) found the species in shallow water. Jarke (1961) found it in the shallower parts of the North Sea, and Buzas (1966) found it at low water depths. Lutze (1965) only found the species in the shallowest water when salinity was more than $15 \%$.

The species seems to belong to the shallower water and to demand a salinity of more than $15 \%$.

\section{Elphidium margaritaceum Cushman 1930 \\ Pl. 2, figs. 13-14.}

1930: Elphidium advenum (Cushman) var. margaritaceum Cushman, p. 25, pl. 10, fig. 3. 1957: Elphidium margaritaceum (Cushman) - van Voorthuysen, p. 32, pl. 23, figs. 13 a, b. 1963: Elphidium margaritaceum (Cushman) - Lafrenz, p. 30, pl. 4, figs. 1, 2.

1967: Elphidium margaritaceum Cushman - Michelsen, p. 240, pl. 5, fig. 7.

Two specimens from Stensigmose were identified as this species on the basis of the figures in the above-mentioned papers. The specimens are in agreement with the description by Michelsen (1967), except that the test is not semitransparent, but opaque white. This is probably in agreement with Cushman (1930), who described the wall as pearly. 
Measurements: Both of the two specimens lack the last chambers, so the measurements are not directly comparable with those given by other authors: Greatest diameter: 0.28 and $0.35 \mathrm{~mm}$.

Thickness: $0.13 \mathrm{~mm}$ for both.

Both specimens had 8 chambers in the last whorl.

Occurrence: The two specimens were found in the Tapes Sand (samples 235 and 246).

Distribution: The species was recorded from the oldest Pleistocene of the Netherlands (van Voorthuysen 1950). Woszidlo (1962) found one specimen in Holsteinian deposits. It was recorded from the Eemian by van Voorthuysen (1957) and by Lafrenz (1963). Cushman (1939) mentioned the species from the Pleistocene. Michelsen (1967) and Feyling-Hanssen et al. (1971) found it in Weichselian and Flandrian deposits. In Recent this species was found at low frequency in tidal areas of the Netherlands (van Voorthuysen 1951, 1960) and Germany (Haake 1962). It was recorded from the east coast of North America at Rhode Island and the southern New England States (Cushman 1930, 1944) and in Long Island Sound and Buzzards Bay (Parker 1952).

Remarks: The two specimens occurring in the Tapes Sand are probably derived from another facies.

Genus Protelphidium Haynes 1956

Protelphidium albiumbilicatum (Weiss 1954)

Pl. 3, figs. 1-3; pl. 5, figs. 1-2.

1954: Nonion pauciloculum albiumbilicatum Weiss, p. 157, pl. 32, figs. 1 a, b, 2.

1957: Nonion depressulus (Walker \& Jacob) forma asterotuberculatus n.f. van Voorthuysen, p. 28 , pl. 23 , figs. 3 a, b.

1963: Nonion pauciloculum Cushman subsp. albiumbilicatum Weiss - Lafrenz, p. 22, pl. 1, figs. 19-22.

1965: Elphidium subarcticum Cushman - Brodniewicz, p. 201, text-fig. 28, pl. 9, figs. 7-14, pl. 11, fig. 13.

1965: Cribrononion asklundi (Brotzen) - Lutze, p. 104, pl. 15, fig. 42.

1969: Protelphidium asterotuberculatus (Voorthuysen) - Gudina, p. 35, pl. 12, fig. 6.

The specimens from Stensigmose are in agreement with the descriptions given by Weiss (1954) and van Voorthuysen (1957). Furthermore the test has an optical radiate wall structure. Investigations by SEM reveal that the species does not have retral processes (pl. 5, figs. 1-2). Some of the specimens may appear to have retral processes. This is probably caused by corrosion of parts of the granular material in the sutures, resulting in the formation of slits of varying length. 
Measurements: Greatest diameter: $0.14-0.56 \mathrm{~mm}$, average $0.29 \mathrm{~mm}$.

Thickness: $0.09-0.19 \mathrm{~mm}$, average $0.13 \mathrm{~mm}$.

Number of chambers in the last whorl: 5-11, mostly 7-8.

Occurrence: This species was the first to occur in the basal marine strata, where it made up almost $100 \%$ of the foraminiferal fauna (samples 109, 110 and 206). Elsewhere in the Cyprina Clay and the Tapes Sand the frequency of the species was mostly less than $1 \%$.

Distribution: The species was recorded from Holsteinian deposits (Woszidlo 1962, Wiegank 1972), from the Rügen Interstadial (Wiegank 1972) and from Eemian deposits in the Netherlands (van Voorthuysen 1957), in northern Germany (Lafrenz 1963, Wiegank 1972) and in western Siberia (Gudina 1969). Weiss (1954) also found it in an interglacial deposit. The species was recorded from Weichselian and Flandrian deposits of Denmark (FeylingHanssen et al. 1971) and from Flandrian deposits of the Oslofjord (FeylingHanssen 1964) and Poland (Brodniewicz 1965). In Recent the species was recorded from the Oslofjord (Risdal 1964), from the Baltic Sea (Rottgardt 1952, Brodniewicz 1965, Lutze 1965) and from the North Sea (van Voorthuysen 1960, Haake 1962).

Remarks: This species is considered to belong to the genus Protelphidium because of the optical radiate wall structure and the lack of retral processes.

As seen from the scattergram Fig. 4, this species includes Nonion pauciloculum albiumbilicatum of Weiss (1954) as well as Nonion depressulus forma asterotuberculatus of van Voorthuysen (1957). This is in agreement with Brodniewicz (1965), Feyling-Hanssen et al. (1971) and Wiegank (1972).

Buzas (1966) showed that Nonion pauciloculum was a synonym of Elphidium subarcticum. Brodniewicz (1965) included Protelphidium albiumbilicatum in Elphidium subarcticum. A comparison between specimens of this species, kindly placed at my disposal by Dr. Feyling-Hanssen, and Protelphidium albiumbilicatum showed a clear difference: the granular material in the sutures of Elphidium subarcticum continued along the sutures and across the margin of the test with the same breadth, whereas the breadth of the granular material in the sutures of Protelphidium albiumbilicatum decreased from the umbilicus to the margin of the test, where it disappeared. Furthermore Woszidlo (1962) found Protelphidium albiumbilicatum and Elphidium subarcticum as two independent species in a fauna and did not mention any transition between the two species. Protelphidium albiumbilicatum is therefore considered to be a specific species. This is in agreement with Feyling-Hanssen et al. (1971) and Wiegank (1972).

Lutze (1965) regarded this species as a form of Brotzen's Elphidium asklundi (1943). This is not the case. Comparisons of this species, kindly 


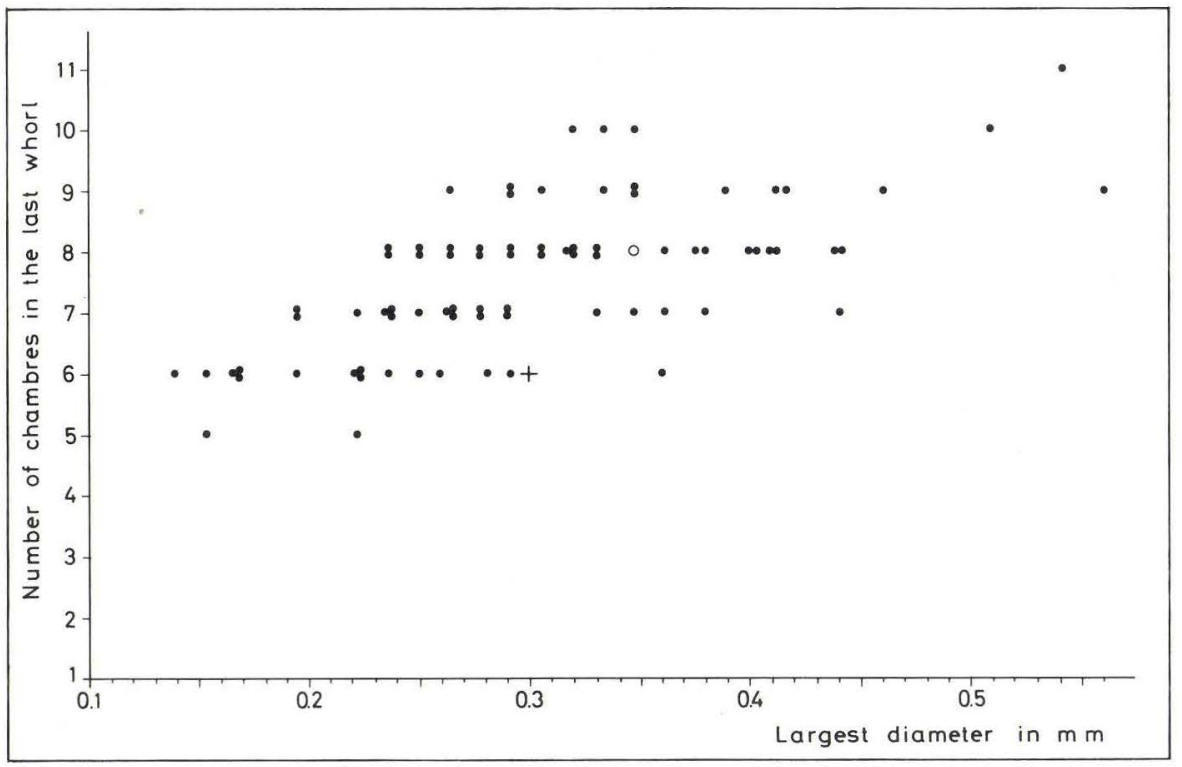

Fig. 4. Scattergram showing the relationships between largest diameter and number of chambers in the last whorl for Protelphidium albiumbilicatum (Weiss). Measured specimens from samples 109, 110, 111, 406 and 407. The circle indicates the specimen figured by Weiss (1954, pl. 32, figs. 1a, 1b). The cross indicates the specimen figured by van Voorthuysen (1957, pl. 23, figs. 3a, 3b).

placed at my disposal by Dr. Feyling-Hanssen, and Protelphidium albiumbilicatum showed the following differences: Elphidium asklundi had a closer perforation and a milky-white appearance; its sutures were straight; it often had a double row of sutural pores, 10-12 chambers in the last whorl, and its largest diameter was around $1.0 \mathrm{~mm}$; Protelphidium albiumbilicatum was not so closely perforated and hyaline; the sutures were strongly backwardcurved close to the margin of the test; it had one row of sutural pores, mostly 7-8 chambers in the last whorl, and its largest diameter was in average $0.28 \mathrm{~mm}$, reaching a maximum of $0.54 \mathrm{~mm}$. Feyling-Hanssen et al. (1971) also demonstrated the difference. They furthermore found the two species as two independent populations without transitions in the Older Yoldia Clay of Vendsyssel.

Gudina (1969) established the species Protelphidium asterotuberculatus on the basis of van Voorthuysen's "forma asterotuberculatus". This species now probably must be included in Protelphidium albiumbilicatum.

Lutze (1965) found this species in the recent Baltic Sea and called it a brackish water species belonging to the brackish surface water at depths of less than $15 \mathrm{~m}$. This is in agreement with Rottgardt (1952), who found the 
species frequently in low salinity areas in the estuary of the river Schlei, eastern Schleswig, and in the Kiel Canal in areas with salinity as low as $31 / 2 \%$.

This species is considered to belong to shallow water and to be a brackish water species, which withstands extremely low salinity.

\section{Protelphidium anglicum Murray 1965}

Pl. 3, figs. 4-5.

1965b: Protelphidium anglicum Murray, p. 149, pl. 25, figs. 1-5, pl. 26, figs. 1-6.

The specimens from Stensigmose are in agreement with the description by Murray (1965b). The last-formed chambers of the last whorl often show a tendency to despiralisation, so that the last chambers tend to suggest an evolute type. Furthermore, the interiomarginal area of the apertural face is often covered by granular material hiding the aperture.

Measurements: Greatest diameter: $0.35-0.53 \mathrm{~mm}$, average $0.43 \mathrm{~mm}$.

Thickness: $0.16-0.24 \mathrm{~mm}$, average $0.19 \mathrm{~mm}$.

Number of chambers in the last whorl: 8-10, mostly 9.

Occurrence: The species was found in the Cyprina Clay and in the Tapes Sand and normally made up less than $5 \%$ of the fauna. In profile No. I its frequency was a little higher, but still less than $10 \%$.

Distribution: Feyling-Hanssen et al. (1971) recorded a few specimens in Weichselian deposits, whereas it was quite frequent in Flandrian deposits. In Recent the species was found on the coasts of Great Britain (Murray 1965 a).

Remarks: Murray (1965 b) stated that previous authors classed the species with Walker \& Jacob's Nonion depressulus. He mentioned that the species was very abundant on the British coasts, particularly in areas of lowered salinity. Therefore this species was probably called Nonion depressulus in papers dealing with similar shallow water areas by van Voorthuysen (1951, 1957, 1960), Rottgardt (1952), Jarke (1961), Haake (1962), Woszidlo (1962) and Lafrenz (1963). This opinion was also expressed by Feyling-Hanssen et al. (1971), but contradicted by Wiegank (1972).

Protelphidium dittmeri (Lafrenz 1963)

Pl. 3, figs. 6-7; pl. 5, figs. 3-4.

1963: Elphidium dittmeri Lafrenz, p. 33, pl. 4, figs. 15-19.

1965: Elphidium kozlowskii Brodniewicz, p. 205, text-fig. 29, pl. 7, fig. 4, pl. 9, figs. 1-6. 
Specimens from Stensigmose are in agreement with the description of Lafrenz (1963), who mentioned that the specimens did not have retral processes. This is also seen in investigations by SEM (pl. 5, figs. 3-4). It might be added that the last-formed chambers of the last whorl often show a slight tendency to despiralisation, as is also seen in Lafrenz' figures (1963, pl. 4, figs. 15, 17).

Measurements: Greatest diameter: $0.23-0.48 \mathrm{~mm}$, average $0.32 \mathrm{~mm}$. Thickness: $0.10-0.19 \mathrm{~mm}$, average $0.15 \mathrm{~mm}$.

Number of chambers in the last whorl: 7-10, mostly 8 .

Occurrence: The species was found in the Cyprina Clay and in the Tapes Sand. It usually made up only a few percent of the fauna, but in the fine sanded Tapes Sand it reached as much as 7-8\%.

Remarks: This species is considered to belong to the genus Protelphidium because of the optical radiate wall structure and the lack of retral processes, as also indicated by Wiegank (1972), who found the species in deposits from the Rügen Interstadial.

Lafrenz (1963) recorded this species in Eemian deposits from the west coast as well as from the east coast of Schleswig-Holstein. Van Voorthuysen (1957) did not mention a species like this one from the Eemian deposit in the Netherlands. Nevertheless, in the assemblage slide which I received from Dr. van Voorthuysen, one specimen of Protelphidium dittmeri was found, classed with Elphidium selseyensis (= Elphidium excavatum). For this reason Protelphidium dittmeri is considered also to occur in the Eemian of the Netherlands.

Brodniewicz (1965) established the new species Elphidium kozlowskii from the recent Baltic Sea. Her description and figures seem to agree so well with Protelphidium dittmeri that this must be the species she found. Lafrenz' name Protelphidium dittmeri therefore has the priority for this species.

Protelphidium magellanicum (Heron-Allen \& Earland 1932)

Pl. 3, figs. 12-13; pl. 5, figs. 5-6.

1932: Elphidium (Polystomella) magellanicum Heron-Allen \& Earland, p. 440, pl. 16, figs. 26-28.

1963: Elphidium magellanicum Heron-Allen \& Earland - Lafrenz, p. 30, pl. 3, figs. 14-16.

1969: Cribrononion magellanicum (Heron-Allen \& Earland) - Lévy, Mathieu, Momeni, Poignant, Rosset-Moulinier, Rouvillois \& Ubaldo, p. 94, pl. 1, fig. 7, pl. 2, figs. 3, 4.

The specimens from Stensigmose are in agreement with the description given by Lafrenz (1963), except that no retral processes are seen as revealed in investigations by SEM (pl. 5, figs. 5-6). The species also has an optical radiate wall structure, as also mentioned by Lévy et al. (1969). 
Measurements: Greatest diameter: 0.25-0.40 $\mathrm{mm}$, average $0.32 \mathrm{~mm}$.

Thickness: $0.13-0.20 \mathrm{~mm}$, average $0.17 \mathrm{~mm}$.

Number of chambers in the last whorl: $5-7$, mostly 6 .

Occurrence: The species was found in the Cyprina Clay and in the Tapes Sand with a frequency of less than $1 \%$. In some of the samples it was missing.

Distribution: Lafrenz (1963) found this species in Eemian deposits, especially in the fine sanded Olander Beds deposited at low water depths. Wiegank (1972) also recorded it from the Eemian. Michelsen (1967) and Feyling-Hanssen et al. (1971) found a few specimens in Weichselian and Flandrian deposits. In Recent it was found by Heron-Allen \& Earland (1932) at water depths of 23 and $82 \mathrm{~m}$ in the Strait of Magellan. Haake (1962) found a few empty tests in samples from tidal areas of northern Germany, whereas Lévy et al. (1969) indicated the species as rather frequent at low water depths around Dunkerque. The same occurrence was indicated by Dupeuble, Mathieu, Momeni, Poignant, Rosset-Moulinier, Rouvillois \& Ubaldo (1971) from the French coast of the Channel. It was not found in the present Baltic Sea (Brodniewicz 1965, Lutze 1965).

Remarks: The species is considered to belong to the genus Protelphidium because of the optical radiate wall structure and the lack of retral processes.

The species can be distinguished from Elphidium subarcticum Cushman, as the former has fewer, but clearly inflated chambers, a lobulate periphery, distinctly depressed sutures, no retral processes and less granular material in the umbilicus and sutures in comparison with Elphidium subarcticum.

Protelphidium magellanicum probably prefers low water depths.

Protelphidium niveum (Lafrenz 1963)

Pl. 3, figs. 8-9; pl. 5, figs. 7-8.

1963: Nonion ? niveum Lafrenz, p. 24, pl. 2, figs. 1-4.

The specimens from Stensigmose are in agreement with the description by Lafrenz (1963). Furthermore the test has an optical radiate wall structure.

Measurements: Greatest diameter: $0.18-0.28 \mathrm{~mm}$, average $0.21 \mathrm{~mm}$.

Thickness: $0.09-0.13 \mathrm{~mm}$, average $0.10 \mathrm{~mm}$.

Number of chambers in the last whorl: 7-9, mostly 8 .

Occurrence: The species was found in the Cyprina Clay and in the Tapes Sand. In the Cyprina Clay it made up more than $10 \%$ of the fauna, reaching a maximum of $25 \%$ in sample 212, whereas in the Tapes Sand it made up less than $10 \%$, in the upper part less than $5 \%$ of the fauna. 
Distribution: The species was recorded from the Rügen Interstadial by Wiegank (1972), from the Eemian by Lafrenz (1963) and from the Weichselian by Feyling-Hanssen et al. (1971).

Remarks: Because of the radiate wall structure this species is considered to belong to the genus Protelphidium, as also stated by Wiegank (1972).

\section{Protelphidium orbiculare (Brady 1881)}

Pl. 3, figs. 10-11.

1881: Nonionina orbicularis Brady, p. 415, pl. 21, fig. 5.

1953: Elphidium orbiculare (Brady) - Loeblich \& Tappan, p. 102, pl. 19, figs. 1-4.

1961: Protelphidium orbiculare (Brady) - Todd \& Low, p. 20, pl. 2, fig. 11.

1962: Nonion orbiculare (Brady) - Woszidlo, p. 72, pl. 2, figs. 15, 16.

The specimens from Stensigmose are in agreement with the description given by Loeblich \& Tappan (1953). In some specimens, slits are formed by corrosion in the sutures, especially near the umbilicus.

Measurements: Greatest diameter: $0.31-0.51 \mathrm{~mm}$, average $0.45 \mathrm{~mm}$.

Thickness: $0.20-0.31 \mathrm{~mm}$, average $0.25 \mathrm{~mm}$.

Numbers of chambers in the last whorl: 8-10, mostly 9.

Occurrence: The species was found in the Cyprina Clay and in the Tapes Sand. It had the highest frequencies in the lowest part of the Cyprina Clay, where it reached a maximum frequency of $37 \%$ (sample 110 a). In the upper part of the Cyprina Clay and in the Tapes Sand the species made up less than $10 \%$ of the fauna, and in the fine sanded Tapes Sand even less than $5 \%$.

Distribution: Van Voorthuysen (1950) recorded this species from the oldest Pleistocene deposits of the Netherlands. It was found in abundance in the lower part of Holsteinian deposits by Buch (1955), Woszidlo (1962) and Wiegank (1972), who also recorded it from the Rügen Interstadial. It was found in Eemian deposits by Lafrenz (1963), but not by van Voorthuysen (1957). It was found in Weichselian and Flandrian deposits by Hessland (1943), Feyling-Hanssen (1964), Michelsen (1967) and Feyling-Hanssen et al. (1971). In Recent the species was recorded mainly from arctic areas: Brady (1881) from Novaya Zemlya and North Atlantic, Cushman (1948) from Hudson Bay and Canadian and Greenland arctic waters, Loeblich \& Tappan (1953) from northern Alaska and Feyling-Hanssen (1964) from Spitzbergen. Todd \& Low (1961) found the species as a rare one at Martha's Vineyard, where it preferred the open water.

Remarks: Cushman (1930) placed the species in the genus Nonion, even though he found certain characteristics of the genus Elphidium. Loeblich \& Tappan (1953) classed the species with the genus Elphidium, on the basis 
of the aperture, the wall structure and slight traces of retral processes in some specimens. Lafrenz (1963) stated that the species had a canalsystem and therefore belonged to the genus Elphidium. Todd \& Low (1961) and Feyling-Hanssen (1964) classed it with the genus Protelphidium. I agree with them, because the specimens from Stensigmose never show any retral processes, thus differing from the genus Elphidium.

Van Voorthuysen (1957) regarded this species as a geographical subspecies of Nonion depressulus (= Protelphidium anglicum). However Woszidlo (1962) showed that Protelphidium anglicum and Protelphidium orbiculare are two independent species. This is in agreement with my investigations, as the two species occur as two independent populations without any transitions in the Eemian strata.

Lutze (1965) mentioned Protelphidium orbiculare, referring to Loeblich \& Tappan (1953), in his synonymy list of Cribrononion incertum subsp. A. As he gave no measurements of this nor any figures, it is not possible to decide if Protelphidium orbiculare is found in the recent Baltic Sea.

Family Rotaliidae Ehrenberg 1839

Genus Ammonia Brünnich 1772

Ammonia batavus (Hofker 1951)

Pl. 3, figs. 14-15.

1951: Streblus batavus Hofker, pp. 448, 500-502, pls. 335, 340, 341.

1962: Streblus batavus Hofker - Haake, p. 52, pl. 6, figs. 6-12.

1963: Streblus batavus Hofker - Lafrenz, p. 34.

1964: Ammonia batavus (Hofker) - Feyling-Hanssen, p. 349, pl. 21, figs. 4-13.

1965: Ammonia beccari (Linnaeus) - Lutze, p. 95, pl. 15, fig. 33.

The specimens from Stensigmose are in agreement with the description of Hofker (1951).

Measurements: Greatest diameter: $0.41-0.50 \mathrm{~mm}$, average $0.48 \mathrm{~mm}$.

Thickness: $0.23-0.29 \mathrm{~mm}$, average $0.26 \mathrm{~mm}$.

Number of chambers in the last whorl: 7-9, mostly 8 .

Occurrence: This species was found in most samples from the Cyprina Clay and the Tapes Sand. It always made up less than $2 \%$ of the fauna, except in the sand layer of profile No. I (sample 113), where it made up $9 \%$ of the fauna.

Distribution: The species was recorded from the Holsteinian (Woszidlo 1962, Wiegank 1972), from the Rügen Interstadial (Wiegank 1972) and from the Eemian of northern Germany (Lafrenz 1963, Wiegank 1972), but not from the Eemian of the Netherlands (van Voorthuysen 1957), where the 
species Ammonia beccari occurred. Ammonia batavus was found in Weichselian deposits (Feyling-Hanssen et al. 1971). It was recorded from Flandrian deposits by Feyling-Hanssen (1964), Brodniewicz (1965), Michelsen (1967) and Feyling-Hanssen et al. (1971). In Recent it was found in the North Sea (Hofker 1951, van Voorthuysen 1951, 1960, Jarke 1961, Haake 1962), in the Oslofjord (Risdal 1964) and in the Baltic Sea (Rottgardt 1952, Lutze 1965).

Remarks: Lutze (1965) did not recognize Hofker's segregation of an independent North Sea species of Ammonia beccari and considered it to be a geographical subspecies. This might be correct, but until further investigations have explained the exact relationships, I will retain the name Ammonia batavus for the species, indicating ecological conditions as in the recent North Sea. This opinion was also advocated by Wiegank (1972).

Haake (1962) showed that three-fourths of the specimens of Ammonia batavus from the open North Sea had an umbilical plug and one fourth had none, whereas in the more extreme environment of the tidal areas the proportion was the reverse. Lafrenz (1963) found that three-fourths of his specimens, mostly originating in the Turitellenton, had no umbilical plug. This is in agreement with the opinion that the Eemian strata found at the west coast of Schleswig-Holstein were deposited in a tidal area (Gripp 1964, p. 224). Most of the specimens found at Stensigmose have no umbilical plug. This may indicate a still more extreme environment.

Van Voorthuysen (1960) found the species in tidal areas with salinity as low as $7 \%$ and with summer temperatures of $20-24^{\circ}$. Lutze (1965) only found the species in the Baltic Sea in areas with a salinity of more than $15 \%$, probably because of the lower temperatures.

This species is regarded as belonging to the shallower water in an environment corresponding to the recent North Sea.

Acknowledgements. I should like to express my most sincere thanks to Dr. $R$. W. Feyling-Hanssen, my teacher of micropaleontology, and my former colleagues of the Department of Micropaleontology, University of Aarhus, as well as my present colleagues at the Geological Survey of Denmark for help, fruitful discussions and valuable criticism.

Special thanks are due to Dr. J. H. van Voorthuysen, Rijks Geologische Dienst, Haarlem, for sending me an assemblage slide with selected specimens. Mrs. J. Hansen typed the manuscript, Miss K. Andersen and Mrs. J. Ørnbjerg made the drawings and Mr. S. Aa. Meldgaard and Mr. O. Neergaard Rasmussen did the photographic work. 


\title{
Dansk sammendrag
}

\author{
Foraminiferer i eemien aflejringer \\ ved Stensigmose, Sydjylland
}

\section{Indledning}

Formålet med denne undersøgelse er at give en beskrivelse af foraminiferselskabet i de aflejringer fra sidste, eem, interglacialtid, der findes som glacialt dislocerede flager i klinten ved Stensigmose på Broagerland.

En oversigt over udviklingen af kendskabet til eem interglaciale aflejringer findes i Madsen, Nordmann \& Hartz's arbejde fra 1908, hvor også klinten ved Stensigmose beskrives. Den marine interglaciale lagserie består dels af Cyprina-leret, dels af det overlejrende Tapes-sand. Den videre udvikling af kendskabet til eem aflejringerne beskrives af Nordmann i 1928, hvor han fastslår, at aflejringerne tilhører den sidste interglacialtid. Dette bekræftes ved hjælp af pollenundersøgelsen af Jessen \& Milthers (1928) og senere også af Heck (1932). En række senere undersøgelser af eem aflejringerne i Nordtyskland er sammenfattet af Gripp (1964). En oversigt over eem aflejringernes udbredelse ses på Fig. 1.

\section{Metoder}

Størstedelen af kystklinten ved Stensigmose er opbygget af glaciale flager. Mange af disse indeholder marine aflejringer fra eem interglacialtiden.

Profil No. I ligger $130 \mathrm{~m}$ nord for »Fiskerhuset«, som er nævnt 'hos Madsen et al. (1908). En skitse af dette profil er gengivet som Fig. 2. Tørvehorisonten ligger på dette sted $12 \mathrm{~m}$ over havniveau.

Den nedre del af profilet, som delvis er dækket af talus, består af smeltevandssand, der viser krydslejringer og strømribber, og som indeholder underordnede lag af ler og grus. Den $\varnothing$ vre grænse af disse lag udgøres af et lag med tydelige strømribber, hvis bølgede overflade følges af lagdelingen i den nederste del af det overlejrende ler. Dette viser vekslende lag af mørkebrun til grålig og lys grålig farve og går jæunt over i det overlejrende grålige ler, der indeholder enkelte sten i den øverste del. Efter en skarp grænse følger tørvehorisonten, som har en varierende tykkelse, idet den har en meget uregelmæssig øvre begrænsning. Den overlejres af en lys gråbrun kalkgytje, der følges af et gråblåt ler. Dette overlejres af et gulbrunt ler 
med en svagt udviklet lagdeling og med spredte molluskskaller. I den øvre del af dette ler findes et ca. $10 \mathrm{~cm}$ tykt sandlag, og over dette ses tynde sandslirer i leret. Herover følger lyst gulbrunt ler, der også indeholder molluskskaller. Øverst i profilet findes et dække af moræneler. Den del af lagserien som indeholder marine molluskskaller er det interglaciale Cyprinaler.

Profil No. II findes $670 \mathrm{~m}$ nord for "Fiskerhuset", og en skitse heraf er gengivet på Fig. 3. Tapes-sandets $\emptyset$ vre grænse ligger i dette profil $12,5 \mathrm{~m}$ over havniveau.

Eem serien underlejres af lyst gråligt sand med en rusthorisont $30 \mathrm{~cm}$ under toppen. Selve eem aflejringen begynder med en kalkgytje, som er hvid i bunden og grå i toppen. Dette går med en jævn overgang på nogle få $\mathrm{cm}$ over i et blåligt ler, som er lidt sandet i bunden, og som indeholder molluskskaller. $40 \mathrm{~cm}$ over kalkgytjen findes et tyndt lag med knuste skaller af blåmusling. Herover findes Cyprina-leret, som er et mørkt, blåligt, stærkt sammenhængende, fedt ler, hvori der ses sammenhængende, men knuste skaller af molboøsters. Leret viser en svagt udviklet lagdeling. I den øvre del skifter farven af Cyprina-leret til lys gråblå, samtidig med at der findes et tiltagende indhold af silt. Efter en jævn overgang på nogle få $\mathrm{cm}$ følger Tapes-sandet, som har en gulgrå farve. I virkeligheden består det af silt, i den nedre del med et vist lerindhold, og kun de $\varnothing$ verste $2,5 \mathrm{~m}$ består af fint sand. I Tapes-sandet ses mange molluskskaller og de fleste af disse er ikke knust. Over Tapes-sandet følger 10-20 cm smeltevandssand, dernæst $1 \mathrm{~m}$ morænegrus og herover 3 m moræneler. Herover og som toppen af klinten findes 1-2 m horisontalt lagdelt smeltevandssand med talrige ler- og siltlag.

I profil No. I er udtaget de 22 prøver, som er angivet på Fig. 2, og i profil No. II er udtaget de 35 prøver som er angivet på Fig. 3.

Prøverne er oparbejdet efter de metoder som er beskrevet af FeylingHanssen (1964), dog er de yderligere slemmet på en $0,063 \mathrm{~mm}$ sigte.

De enkelte foraminiferarters procentvise hyppigheder i prøverne er afbildet i tabel 1 og 2 . Her er også angivet det beregnede antal foraminiferer i $100 \mathrm{~g}$ tørt sediment, artsspredningen efter Walton (1964) og endelig er bemærket forekomsten af molluskfragmenter, ostracoder, diatomeer, svampenåle og planterester.

\section{Resultater}

For at kunne benytte et faunaselskab ved udredningen af de økologiske og stratigrafiske forhold af en aflejring, må faunaen være primær i aflejringen. Man må derfor være opmærksom på, at faunaen dels kan have været udsat for sekundære ændringer efter aflejringen, og dels er der ofte tale om et allochtont selskab. 
I den marine interglaciale aflejring findes en del foraminiferer, der er omlejret fra den prækvartære undergrund. Et billede af hvilke former det drejer sig om, er opnået ved at undersøge foraminiferindholdet i de glaciale og lacustine aflejringer, som findes under de marine eem aflejringer.

Faunaselskabet viser en ændring i sammensætningen i overensstemmelse med ændringen i sedimentet fra ler via silt til fint sand. Faunaselskabet i leret omkring prøve 210-212 er afsat på den største havdybde, som sandsynligvis har været mere end $15 \mathrm{~m}$. Op gennem profilet viser foraminiferselskabet tegn på en aftagende havdybde, og i det finsandede Tapes-sand tyder det på en ganske lav vanddybde. En sammenligning mellem tabel 1 og 2 viser at profil No. I er aflejret på lidt lavere vand, antagelig tættere ved kysten, hvilket bekræftes af forekomsten af sandlaget i profilet. Dette sand synes at være skyllet ud i bassinet fra en kystnær aflejring.

Saliniteten i det interglaciale hav har været over $20 \%$, da Cyprina-leret blev afsat, mens den er faldet til under $20 \%$, da Tapes-sandet blev afsat.

Foraminiferselskabet tyder på en stigning af temperaturen i den nedre del af Cyprina-leret, mens der ikke er tegn på en aftagen af temperaturen i den $\varnothing$ vre del af lagserien.

Ud fra de foregående undersøgelser kan det følgende sluttes om dannelsen af de undersøgte aflejringer:

Det smeltevandssand, som findes nederst i profil No. I, er formodentlig dannet sidst i saale istiden. Den flod, som aflejrede dette sediment, har pludseligt ændret sit løb, og i den tidligere flodseng er der opstået en sø, hvori det lagdelte ler er afsat. Årsagen til lagdelingen kendes ikke, men aftager gradvis, og det lagdelte ler går over i det grå ler. Derpå har bassinet antagelig været tørlagt. Efter en stigning i grundvandsspejlet er først tørven dannet, og efter yderligere vandstandsstigning er der dannet en $s \emptyset$, hvori kalkgytjen er aflejret inden kalken blev udvasket fra omgivelserne antagelig tidligt i eem interglacialtiden.

Udviklingen til dette punkt i profil No. II har en kortere historie. Det basale lagdelte sand er formodentlig smeltevandssand fra saale istiden, og rusthorisonten kan tænkes dannet af nedsivende vand, mens aflejringen i nogen tid har været over grundvandsspejlet, antagelig i sen saale eller tidlig eem tid. Derpå er grundvandsstanden igen steget, og der er straks blevet dannet en $\varsigma \varnothing$, hvori kalkgytjen er afsat $\mathrm{i}$ tidlig eem interglacialtid.

Udviklingen er derefter forløbet parallelt i de to profiler, blot er mægtighederne forskellige, idet profil No. I har de største mægtigheder. En sammenligning mellem tabel 1 og 2 viser, at profil No. I representerer den nedre del af profil No. II. Over kalkgytjen er der aflejret ler, hvis nederste del er afsat $\mathrm{i}$ en ferskvandssø. Havet er derpå trængt ind i bassinet. Først har det haft meget lav salinitet, men snart efter er denne steget, antagelig 
på grund af en bedre forbindelse med det åbne hav. Denne forbindelse har været kraftigere end for den nuværende Østers $\varnothing$. I det marine bassin er først Cyprina-leret blevet aflejret på havdybder, der for profil No. II's vedkommende hurtigt nåede mere end $20 \mathrm{~m}$. Da den $\varnothing v$ re del af Cyprina-leret blev afsat, er havdybden aftaget igen, og dette er fortsat under aflejringen af Tapes-sandet, der til sidst er afsat på ganske grundt vand.

Det overlejrende smeltevandssand og morænegrus og -ler må tilhøre weichsel istiden, ligesom det horisontalt aflejrede smeltevandssand og -ler på toppen af klinten. Dette må være aflejret efter at flagerne med de interglaciale aflejringer er skudt sammen i det bakkedrag, hvori kystklinten er eroderet.

Van Voorthuysen (1957) fandt i hollandske eem aflejringer en foraminiferfauna, der svarer ret godt til den undersøgte. Han anså klimaet i eem interglacialtiden i Holland for at svare til klimaet i det sydlige Nords $\varnothing$ område i dag eller lidt varmere, men bestemt ikke med lusitansk eller mediterran temperatur. Til forskel fra aflejringen i Holland indeholder eem aflejringen ved Stensigmose et koldt fauna element, som må tilskrives lokalitetens nordligere placering.

Lafrenz (1963) kom til et tilsvarende resultat og fandt også en temperaturstigning i den nedre del af aflejringen. Ved at sammenligne hans profil (tabel 7) fra Stensigmose med mine tabeller, må jeg konkludere, at de aflejringer, som Lafrenz har unders $\emptyset$ gt ved Stensigmose, svarer til den $\emptyset$ vre del af mit profil No. II, Tapes-sandet.

Nordmann (1908, s. 246 ff.) fandt ved undersøgelser af molluskerne i Cyprina-leret et koldt og et varmt element i faunaen. Det samme findes også blandt foraminifererne. Nordmann konkluderer dog på grundlag af adskillige lusitanske arter, at forholdene i Cyprina-leret har svaret til forholdene i Kanalen eller ved Frankrigs vestkyst i dag. Dette afviger lidt fra resultaterne af foraminiferundersøgelserne. Der kan være flere årsager hertil. Dels kan kendskabet til arternes nuværende udbredelse være for begrænset, og dels kan arternes udbredelsesmønster være anderledes på grund af forskelligheder i miljøforholdene eller indvandringshastigheder efter istiderne.

Den marine kvartære aflejring ved Strandegaards Dyrehave er blevet henført til eem interglacialtiden på grundlag af foraminiferindholdet (Petersen \& Konradi 1974), der dels bestod af det karakteristiske eem-selskab, men desuden indeholdt andre arter, som ikke er kendt fra Stensigmose. Aflejringen er derfor afsat under lidt andre $\emptyset$ kologiske forhold.

Den nedre del af Skærumhede II boringen (Bahnson et al. 1973) blev henført til eem interglacialtiden på grundlag af foraminiferfaunaens økologiske indikationer. Foruden karakteristiske "varme" former, som er kendt 
fra sydlige beliggende eem aflejringer, indeholdt faunaen foraminiferer, der viste, at aflejringen er afsat $\mathrm{i}$ en mere åbent havs facies. Skærumhede II boringens interglaciale afsnit blev korreleret med den $\emptyset \mathrm{vre}$ del af Turritella terebra Zonen og Abra nitida Zonen i Skærumhede Serien. 


\section{References}

Andersen, H. V. 1952: Bucella, a new genus of the rotalid foraminifera. - Jour. Washington Acad. Sci. 42 (5), p. 144.

Andersen, S. T. 1965: Interglacialer og interstadialer i Danmarks kvartær. - Meddr dansk geol. Foren. 15 (4), pp. 486-506.

Andersson, F. 1898: Über die quartäre Lagerserie des Ristinge Klint auf Langeland. - Bull. geol. Inst. Univ. Upsala 3, pp. 115-180.

Bahnson, H., Petersen, K. Strand, Konradi, P. B. \& Knudsen, K. L. 1974: Stratigraphy of Quaternary deposits in the Skærumhede II boring: lithology, molluscs and foraminifera. - Danm. geol. Unders., Årbog 1973, pp. 25-58.

Brady, H. B. 1879: Notes on some of the reticularian Rhizopoda of the "Challenger" Expedition. II - Additions to the knowledge of porcellanous and hyaline types. - Quart. Journ. Micr. Sci. 19, p. 285.

Brady, H. B. 1881: On some Arctic foraminifera from soundings obtained on the AustroHungarian North-Polar Expedition of 1872-1874. - Ann. Mag. Nat. Hist. V, 8 (48), p. 415.

Brand, E. 1941: Die Foraminiferen-Fauna des Jade-Gebietes. III. Die Foraminiferen-Fauna im Alluvium des Jade-Gebietes. - Seckenbergiana 23, pp. 56-70.

Brelie, G. v. d. 1951: Die junginterglazialen Ablagerungen in Gebiet des Nord-Ostsee-Kanals. - Schr. naturw. Ver. Schlesw.-Holst. 25, pp. 100-107.

Brodniewicz, I. 1965: Recent and some Holocene foraminifera of the southern Baltic Sea. Acta palaeont. Polonica 10 (2), pp. 131-248.

Brodniewicz, I. 1969: Die Eem-Foraminiferen der Cardiumbank bei Elblag (VR Polen). - Ber. deutsch. Ges. geol. Wiss. A 14 (4), pp. 533-535.

Brotzen, F. 1943: Appendix. In: Hessland, I. Marine Schalenablagerungen Nord-Bohusläns. Bull. geol. Inst. Univ. Upsala 31, pp. 267-268.

Brotzen, F. 1948: The Swedish Paleocene and its foraminiferal fauna. - Avh. Sver. Geol. Unders. C 493, p. 57, 64.

Buch, A. 1955: De marine interglaciale lag ved Inder Bjergum. - Meddr dansk geol. Foren. 12 (6), pp. 593-652.

Buzas, M. A. 1966: The discrimination of morphological groups of Elphidium (Foraminifer) in Long Island Sound through canonical analysis and invariant characters. - Journ. Pal. 40 (3), pp. 585-594.

Cole, W. S. 1931: The Pliocene and Pleistocene foraminifera of Florida. - Bull. Florida State Geol. Surv. 6, p. 34.

Cushman, J. A. 1913: A monograph of the Foraminifera of the North Pacific Ocean. Part III. Lagenidae. - Bull. U. S. Nat. Mus. 71 (3), 125 pp.

Cushman, J. A. 1922: Results of the Hudson Bay Expedition 1920. I - The Foraminifera. Contr. to Canadian Biology 1921 (9), pp. 135-147.

Cushman, J. A. 1923: The foraminifera of the Atlantic Ocean. Part 4. Lagenidae. - Bull. U. S. Nat. Mus. 104 (4), 228 pp.

Cushman, J. A. 1929: The foraminifera of the Atlantic Ocean. Part 6. Miliolidae, Ophthalmidiidae and Fischerinidae. - Bull. U S. Nat. Mus. 104 (6), 129 pp. 
Cushman, J. A. 1930: The foraminifera of the Atlantic Ocean. Part 7. Nonionidae, Camerinidae, Peneroplidae, and Alveolinellidae. - Bull. U. S. Nat. Mus. 104 (7), 79 pp.

Cushman, J. A. 1933: New Arctic foraminifera collected by Captain R. A. Bartlett from Fox Bassin and off the northeast coast of Greenland. - Smithsonian Misc. Coll. 89 (9), 8 pp.

Cushman, J. A. 1939: A monograph of the Foraminiferal Family Nonionidae. - U. S. Geol. Surv. prof. Paper 191, 100 pp.

Cushman, J. A. 1944: Foraminifera from the shallow water of the New England Coast. Cushman Lab. foram. Res., spec. Publ. 12, 37 pp.

Cushman, J. A. 1948: Artic Foraminifera. - Cushman Lab. foram. Res., spec. Publ. 23, 80 pp.

Cushman, J. A. \& Ozawa, Y. 1930: A monograph of the foraminiferal family Polymorphinidae, Recent and Fossil. - Proc. U. S. Nat. Mus. 77 (6), 195 pp.

Dam, A. ten 1944: Die stratigrafische Gliederung des niederländischen Paleozäns und Eozäns nach Foraminiferen. - Med. geol. Sticht. C-V-1 3, p. 112.

Dam, A. ten \& Reinholdt, T. 1941: Die stratigraphische Gliederung des Niederländischen Plio-Pleistozäns nach Foraminiferen. - Med. geol. Sticht. C-V-1 1, 66 pp.

Dittmer, E. 1941: Das nordfriesische Eem. Ein Beitrag zur Geschichte der junginterglazialen Nordsee. - Kieler Meeresforschungen 5 (1), pp. 169-199.

Dittmer, E. 1951: Das Eem des Treenetals. - Schr. naturw. Ver. Schlesw-Holst. 25, pp. 91-99.

Ehrenberg, C. G. 1840: Über die Bildung der Kreidefelsen und des Kreidemergels durch unsichtbare Organismen. - K. Akad. Wiss. Berlin, Physik. Abh. Jahrg. 1838, p. 135.

Ellis, B. F. \& Messina, A. R. 1964: Catalogue of foraminifera. - Am. Mus. Nat. His., Spec. Pub., Sec. microfilm ed., New York.

Feyling-Hanssen, R. W. 1964: Foraminifera in the late Quarternary deposits from the Oslofjord area. - Norges Geol. Unders. 225, 383 pp.

Feyling-Hanssen, R. W. 1972: The foraminifer Elphidium excavatum (Terquem) and its variant forms. - Micropaleontology 18 (3), pp. 337-354.

Feyling-Hanssen, R. W., Jørgensen, J. A., Knudsen, K. L. \& Andersen, A. L. 1971: Foraminifera from the Late Quaternary of Vendsyssel and Sandness in Scandinavia. - Bull. geol. Soc. Denmark 21 (2-3), $317 \mathrm{pp}$.

Gehl, O. 1961: Neue Ergebnisse über das marine Eem und zur Gliederung des Jungpleistozäns in NW-Mecklenburg. - Geologi 10 (4/5), pp. 396-408.

Gibson, L. B. 1966: Some unifying characteristics of species diversity. - Contr. Cushman Found. foram. Res. 17 (4), pp. 117-124.

Gottsche, C. 1904: Über den Tapes-Sand von Steensigmoos. - Z. dt. geol. Ges. 56, pp. $181-184$.

Gripp, K. 1964: Erdgeschichte von Schleswig-Holstein. - Neumünster: Karl Wachholtz, pp. 215-230.

Gudina, V. I. 1969: The marine Pleistocene of the Sibirian Lowlands. Foraminifera of the north part of the Yenisei Lowland. - Akad. Nauk. SSSR. Siberian dept., Inst. Geol. and Geoph. 63, 80 pp. (In Russian).

Haake, F. W. 1962: Untersuchungen an der Foraminiferen-Fauna im Wattgebiet zwischen Langeoog und dem Festland. - Meyniana 12, pp. 25-64.

Haake, F. W. 1967: Zum Jahresgang von Populationen einer Foraminiferen-Art in der westlichen Ostsee. - Meyniana 17, pp. 13-27.

Harder, P. 1900: En ny sønderjydsk lokalitet for marint diluvium. - Meddr dansk geol. Foren. 1 (6), pp. 83-96.

Haynes, J. 1956: Certain smaller British foraminifera. Part I - Nonionidae, Chilostomellidae, Epistomenidae, Discorbidae, Amphisteginidae, Globigerinidae, Globorotaliidae and Gümbelinidae. - Contr. Cushman Found. foram. Res. 7 (3), p. 86. 
Heck, H. L. 1932: Die Eem- und ihre begleitenden Junginterglazial-Ablagerungen bei Oldenbüttel in Holstein. - Abh. Preuss. geol. Landesanst., N. F. 140, 80 pp.

Heck, H. L. \& Brockmann, C. 1950: Eem- Ablagerungen bei Lübeck. - Schr. naturw. Ver. Schlesw.-Holst. 24 (2), pp. 80-86.

Heron-Allen, E. \& Earland, A. 1909: On the recent and fossil foraminifera of the shoresands of Selsey Bill, Sussex. Part IV. - Jour. Roy. Micr. Soc.

Heron-Allen, E. \& Earland, A. 1911: On the recent and fossil foraminifera of the shore-sands of Selsey Bill, Sussex. Part VIII: Tabular list of species and localities. - Jour. Roy Micr. Soc.

Heron-Allen, E. \& Earland, A. 1932: Foraminifera. Part I - The ice-free area of the Falkland Islands and adjacent seas. - Discovery Rep. 4, pp. 291-460.

Hessland, I. 1943: Marine Schalenablagerungen Nord-Bohusläns. - Bull. geol. Inst. Univ. Upsala 31, pp. 1-348.

Hofker, J. 1951: The foraminifera of the Siboga Expedition; Part III. - Monogr. SibogaExped. 46 (3), 513 pp.

Jarke, J. 1961: Die Beziehungen zwischen hydrographischen Verhältnissen, Faziesentwicklung und Foraminiferenverbreitung in der heutigen Nordsee als Vorbild für die Verhältnisse während der Miocän-Zeit. - Meyniana 10, pp. 21-36.

Jessen, K. \& Milthers, V. 1928: Stratigrafical and Paleontological Studies of Interglacial Fresh-water Deposits in Jutland and Northwest Germany. - Danm. geol. Unders. II Række, 48, 379 pp. + Atlas.

Lafrenz, H. R. 1963: Foraminiferen aus den marinen Riss-Würm-Interglazial (Eem) in Schleswig-Holstein. - Meyniana 13, pp. 10-46.

Le Calvez, J. \& Le Calvez, Y. 1951: Contribution a l'études de foraminifères des eaux saumatres; Etanges de Canets et de Salses. - Vie et Milieu 2 (2), pp. 237-254.

Levy, A. 1966: Contribution á l'étude écologique et micropaléontologique de quelques Elphidium (Foraminifères) de Roussillon. Description d'une nouvelle espèce: Elphidium cuvillieri n. sp. - Vie et milieu 17 (I. A.), pp. 1-8.

Levy, A., Mathieu, R., Momeni, I., Poignant, A., Rosset-Moulinier, M., Rouvillois, A. \& Ubaldo, M. 1969: Les reprèsentants de la famille des Elphidiidae (foraminifères) dans les sables des plages des environs de Dunkerque. Remarques sur les espèces de Polystomella signalées par O. Terquem. - Rev. Micropaleont. 12 (2), pp. 92-98.

Linne, C. von. 1758: Systema naturae. Ed. 10. Holmiae 1, p. 786.

Loeblich, A. R. \& Tappan, H. 1953: Studies of Arctic Foraminifera. - Smithsonian Misc. Coll. 121 (7), $150 \mathrm{pp}$.

Loeblich, A. R. \& Tappan, H. 1964: Protista 2. Sarcodina. Chiefly "Thecamoebians" and Foraminiferida. In: Moore, R. C. (ed.) Treatise on invertebrate Paleontology, Part C, I-II, Geol. Soc. Amer. and Univ. Kansas Press. 900 pp.

Lutze, G. F. 1965: Zur Foraminiferenfauna der Ostesee. - Meyniana 15, pp. 75-142.

Lutze, G. F. 1968: Jahresgang der Foraminiferen-Fauna in der Bottsand-Lagune. - Meyniana 18, pp. 13-30.

Madsen, V. 1895: Istidens Foraminiferer i Danmark og Holsten. - Meddr dansk geol. Foren. 1 (2), $229 \mathrm{pp}$.

Madsen, V., Nordmann, V. \& Hartz, N. 1908: Eem-Zonerne. Studier over Cyprinaleret og andre Eem-Aflejringer i Danmark, Nordtyskland og Holland. - Danm. geol. Unders. II. Række, 17, 302 pp. + Atlas.

Michelsen, O. 1967: Foraminifera of the Late-Quaternary Deposits of Læsø. - Meddr dansk geol. Foren. 17 (2), pp. 205-265. 
Montagu, G. 1803: Testacea Britannica, or natural history of British shells, marine, land and fresh-water, including the most minute. - Romsey: J. S. Hollis, p. 523.

Munthe, H. 1898: Studien über ältere Quartärablagerungen im südbaltischen Gebiete. - Bull. geol. Inst. Univ. Upsala 3, pp. 27-114.

Murray, J. W. 1965 a: On the foraminiferida of the Plymouth region. - Jour. Mar. Biol, Ass. U. K. 45, pp. 481-505.

Murray, J. W. 1965 b: Two Species of British Recent Foraminiferida. - Contr. Cushman Found. Foram. Res. 3 (4), pp. 148-150.

Nordmann, V. 1928: La Position stratigrafique des Dépots d’Eem. - Danm. geol. Unders. II Række, 47, 81 pp.

Nørvang, A. 1945: Foraminifera. In: The Zoology of Iceland. 2 (2), - Copenhagen and Reykjavik: Munksgård, $79 \mathrm{pp}$.

d'Orbigny, A. D. 1826: Tableau méthodique de la classe des Céphalopodes. III' ordre. Foraminifères. - Annls Sci. nat., ser. 1, 7, p. 253, 254, 266, 269, 277, 278.

d'Orbigny, A. D. 1839: Voyage dans l'Amerique méridional. - Foraminifères. - Strasbourg: Levrault 5 (5), p. 21, 30.

d'Orbigny, A. D. 1840: Mèmoire sur les Foraminifères de la Craie Blanche du Bassin de Paris. - Mém. Soc. Géol. France 4 (1), p. 34.

d'Orbigny, A. D. 1846: Foraminifères fossils du Bassin tertiaire de Vienne. - Paris: Gide et Comp., p. 186, 187, 223, 240.

Parker, F. L. 1948: Foraminifera of the continental shelf from the Gulf of Maine to Maryland. - Bull. Mus. comp. Zool. 100 (2), pp. 211-242.

Parker, F. L. 1952: Foraminiferal distribution in the Long Island Sound - Buzzards Bay area. - Bull. Mus. comp. Zool. 106 (10). pp. 425-473.

Parker, F. L. 1954: Distribution of the Foraminifera in the northeastern Gulf of Mexico. Bull. Mus. comp. Zool. 111 (10), pp. 453-588.

Petersen, K. Strand \& Konradi, P. B. 1974: Lithologisk og palæontologisk beskrivelse af profiler i Kvartæret på Sjælland. - Dansk geol. Foren., Årsskrift for 1973, pp. 47-56.

Phleger, F. B. 1952: Foraminifera distribution in some sediment samples from the Canadian and Greenland Arctic. - Contr. Cushman Found. foram. Res. 3, pp. 80-89.

Phleger, F. B. 1960: Ecology and Distribution of Recent Foraminifera, 297 p. - Baltimore: John Hopkins Press.

Pokorný, V. 1963: Principles of zoological micropaleontology. Volume I. - Oxford: Pergamon Press, pp. 91-471.

Reuss, A. E. 1851: Über die fossilen Foraminiferen und Entomostraceen der Septapienthone der Umgegend von Berlin. - Z. dt. geol. Ges. 3., p. 71.

Risdal, D. 1964: Foraminiferfaunaens relasjon til dybdeforholdene i Oslofjorden, med en diskusjon av de senkvartære foraminiferzoner. - Norges geol. Unders. 226, 142 pp.

Rottgardt, D. 1952: Mikropaläontologisch wichtige Bestandtiele recenter brakischer sedimente an den Küsten Schleswig-Holsteins. - Meyniana 1, pp. 169-228.

Seguenza, G. 1862: Prime riserche intorno ai rizopodi fossili delle argille Pleistoceniche dei dintorni di Catania. - Accad. Gioenia Sei. Nat. Catania, ser. 2, 18, p. 109.

Sindowski, K.-H. 1959: Das Eem im Wattgebiet zwischen Norderney und Spiekeroog, Ostfriesland. - Geol. Jb. 76, pp. 151-174.

Tappan, H. 1951: Northern Alaska index Foraminifera. - Contr. Cushman Found. foram. Res. 2, pp. $1-8$.

Terquem, O. 1875: Essai sur le Classement des Animaux qui vivent sur la Plage et dans les Environs de Dunkerque. 1. Paris. 
Terquem, O. 1876: Essai sur le Classement des Animaux qui vivent sur la Plage et dans les Environs de Dunkerque. 1. - Mém. Soc. Dunkerquoise 19, pp. 405-458.

Terquem, O. 1882: Les foraminifères de l'Eocene des environs de Paris. - Mem. Soc. Geol. France, ser. 3, 2, p. 3, 31.

Todd, R. \& Low, D. 1961: Near-Shore Foraminifera of Martha's Vineyard Island, Massachusetts. - Contr. Cushman Found. foram. Res. 12 (1), pp. 5-21.

Voorthuysen, J. H. van. 1950: The quantitative Distribution of the Pleistocene, Pliocene and Miocene Foraminifera of the Boring Zaandam (Netherlands). - Med. geol. Sticht., nieuwe ser. 4, pp. 51-62.

Voorthuysen, J. H. van. 1951: Recent (and derived Upper Cretaceous) Foraminifera of the Netherlands Wadden Sea (Tidal Flats). Med. geol. Sticht., nieuwe Ser. 5, pp. 23-32.

Voorthuysen, J. H. van. 1957: Foraminiferen aus dem Eemien (Riss-Würm - Interglazial) in der Bohrung Amersfoort I (Locus Typicus) - Med. geol. Sticht, nieuwe ser. 11, pp. 27-39.

Voorthuysen, J. H. van. 1960: Die Foraminiferen des Dollart-Ems-Estuarium. In: Symposium Ems-Estuarium (Nordsee). - Verh. Kon. Ned. Geol. Mijub. K. Gen., Geol. ser. 19, pp. 237-269.

Walker, G. \& Jacob, E. 1798: In: Kanmacher, F.: Adams' Essays on the microscope. Ed. 2. - London: Dillon and Keating, p. 634, 641.

Walton, W. R. 1960: Diagnostic faunal characteristics on and near a barrier island, Horn Island, Mississippi. - Trans Gulf. Cst. Ass. geol. Socs. 10, pp. 7-24.

Walton, W. R. 1964: Recent Foraminiferal Ecology and Palecology. In: Imbrie, J. and Newell, N. (Editors): Approaches to Palecology - New York: Wiley, pp. 151-237.

Weiss, L. 1954: Foraminifera and origin of the Gardiners clay (Pleistocene), eastern Long Island, New York. - U. S. geol. Surv. prof. Paper 254-G, pp. 139-163.

Wiegank, F. 1972: Ökologische Analyse quartärer Foraminiferen. Beitrag zur Quartärstratigraphi in der nördlichen Deutschen Demokratischen Republik. - Geologie 21, Beih. $77,111 \mathrm{pp}$.

Williamson, W. C. 1848: On the Recent British species of the genus Lagena. - Ann. Mag. Nat. Hist., ser. 2, 1, p. 20.

Williamson, W. C. 1858: On the Recent Foraminifera of Great Britain. - London: Ray Society, $107 \mathrm{pp}$.

Woszidlo, H. 1962: Foraminiferen und ostracoden aus dem marinen Elster-Saale Interglazial in Schleswig-Holstein. - Meyniana 12, pp. 65-96. 


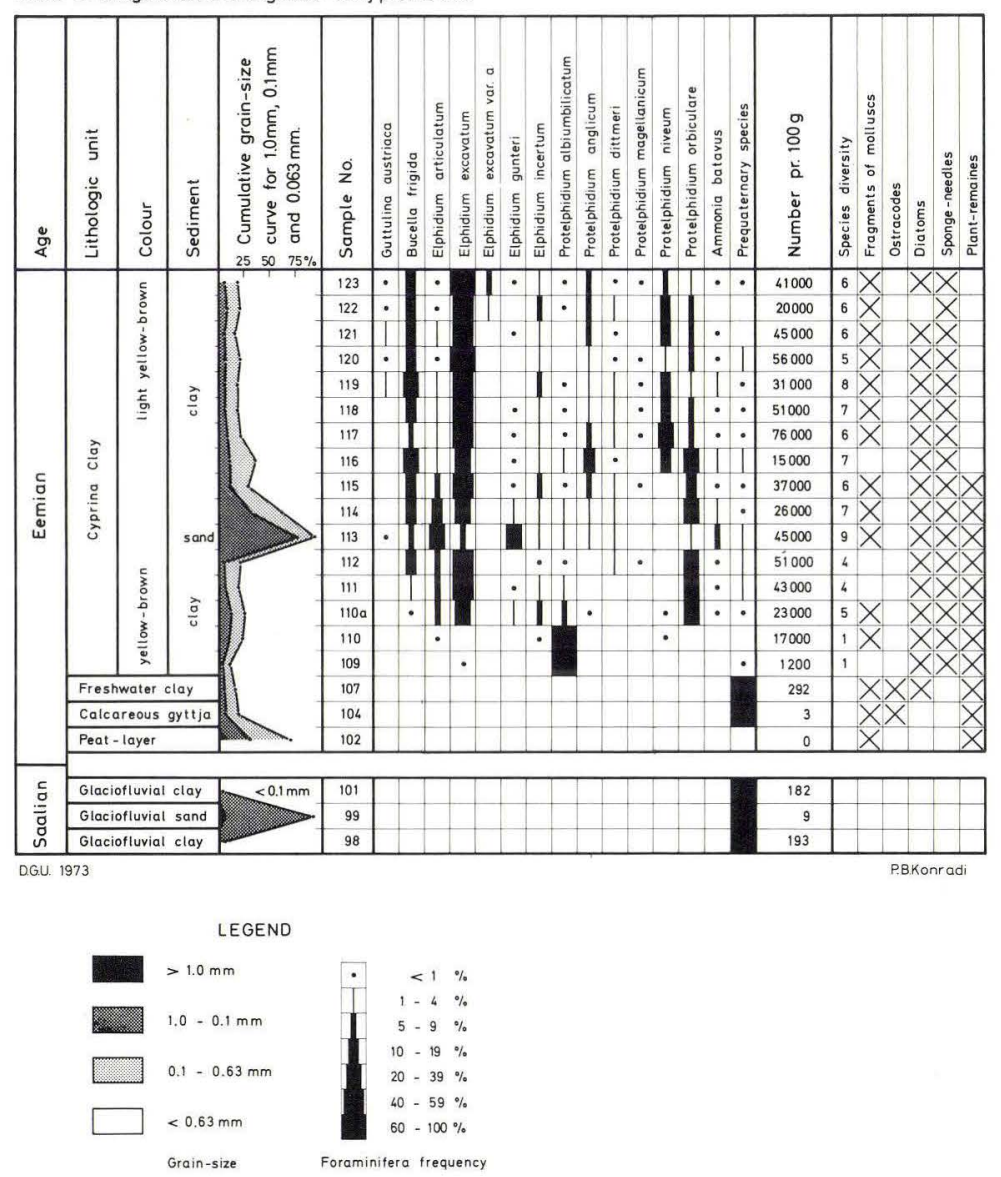




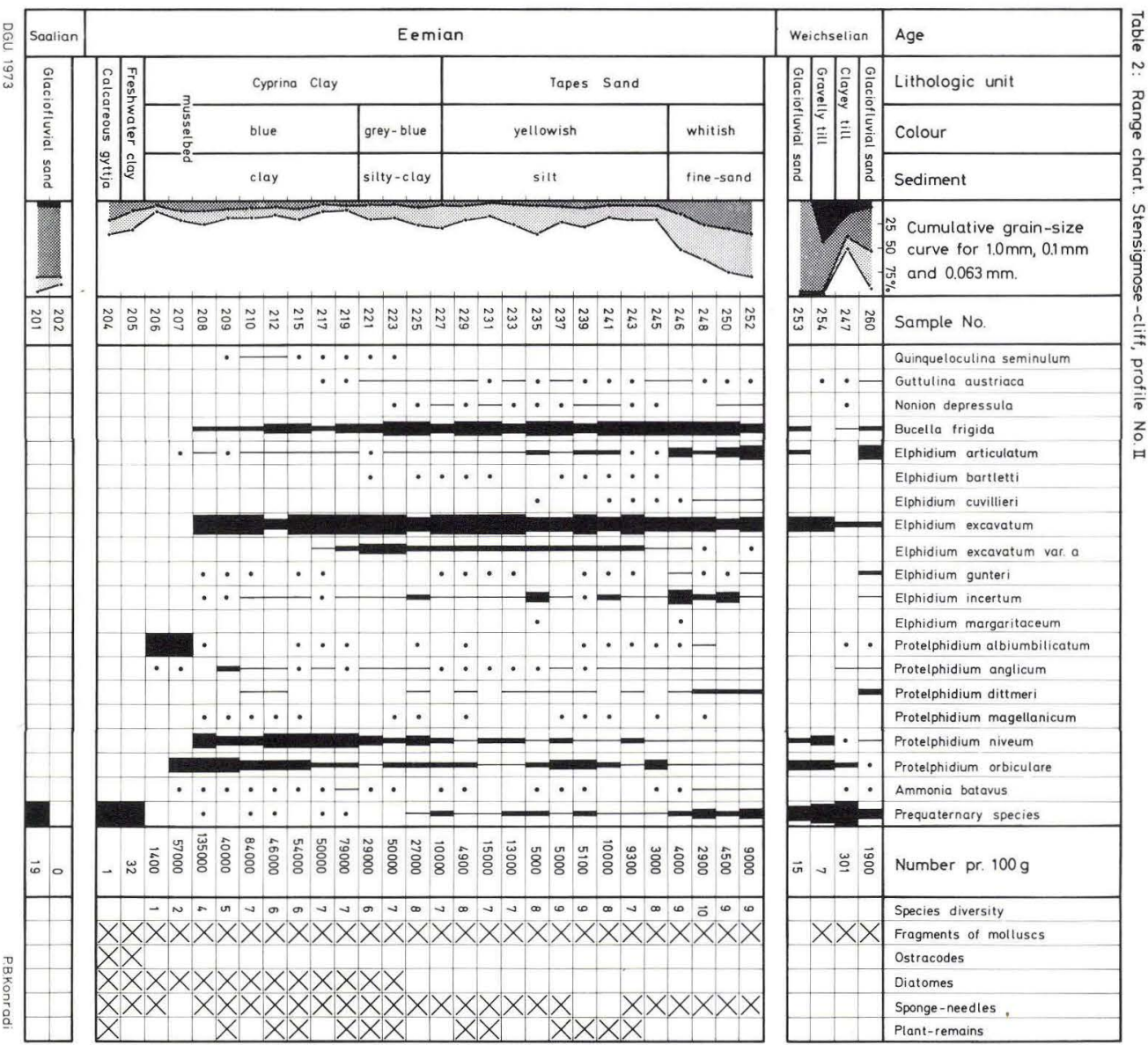


Plates 
Plate 1

D. G. U. Text

Fig. 1. Quinqueloculina seminulum (Linné 1758);

sample $210 ; \times 60 \ldots \ldots \ldots \ldots \ldots \ldots \ldots \ldots \ldots \ldots$
Figs. 2-3. Nonion depressula (Walker \& Jacob 1798)

1972-PBK-1 24 emend. Murray 1965; sample 241; × $80 \ldots \ldots$ 1972-PBK-3 26

Fig. 4. Guttulina austriaca d'Orbigny 1846; sample $120 ; \times 80 \ldots \ldots \ldots \ldots \ldots \ldots \ldots \ldots$ 1972-PBK-2 25

Figs. 5-6. Buccella frigida (Cushman 1922) emend. Andersen 1952; sample 111; × $80 \ldots \ldots$ 1972-PBK-4 27 5: Spiral view, 6: Umbilical view.

Figs. 7-8. Elphidium articulatum (d'Orbigny 1839); sample $111 ; \times 80 \ldots \ldots \ldots \ldots \ldots \ldots \ldots$. 1972-PBK-5 28

Figs. 9-10. Elphidium bartletti Cushman 1933; sample $227 ; \times 80 \ldots \ldots \ldots \ldots \ldots \ldots \ldots$ 1972-PBK-6 29

Figs. 11-12. Elphidium bartletti Cushman 1933; corroded specimen; last chambers missing; sample $241 ; \times 80$ 


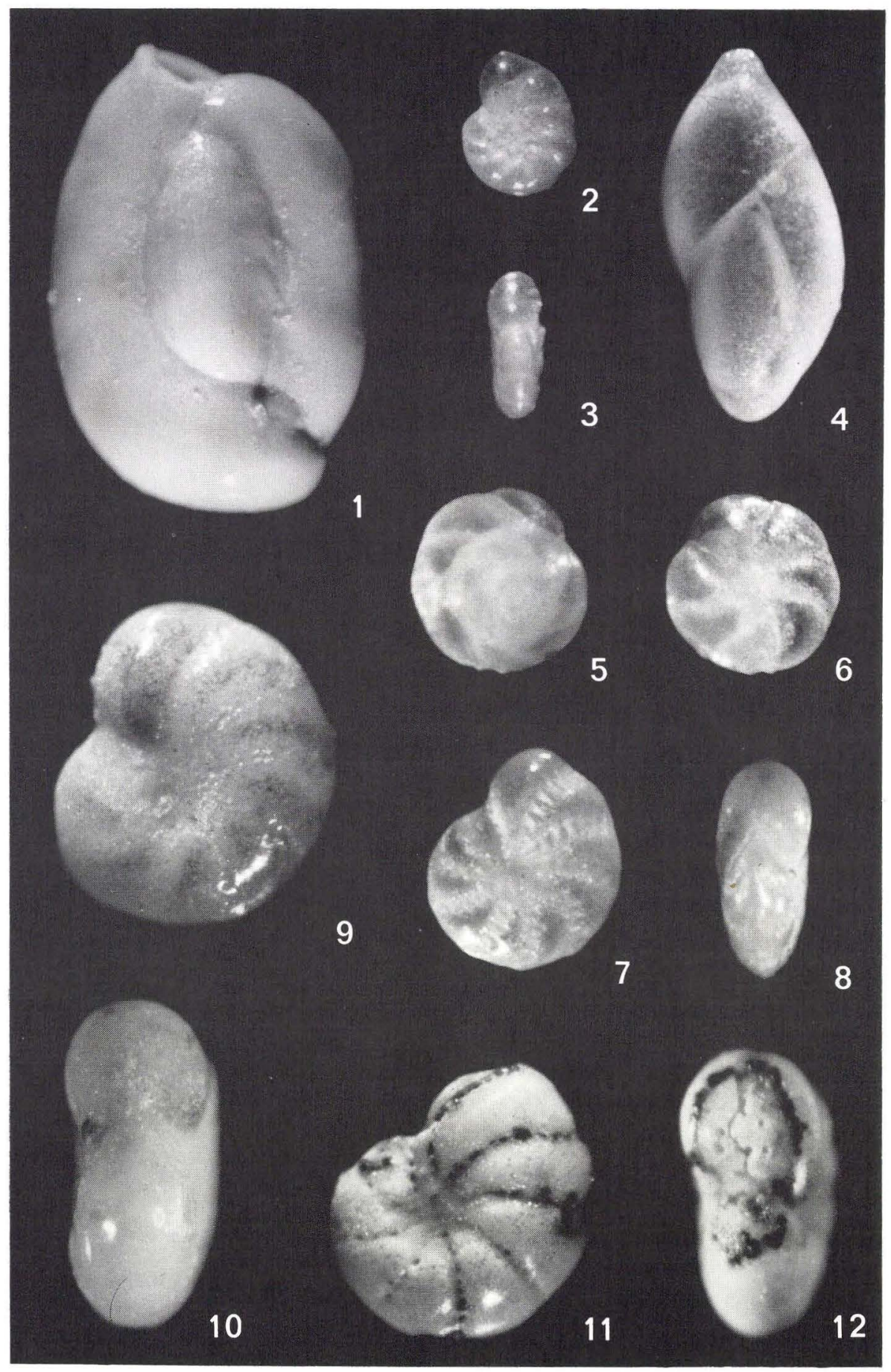


Plate 2

D. G. U. Text

Figs. 1-2. Elphidium cuvillieri Lévy 1966;

sample $248 ; \times 80 \ldots \ldots \ldots \ldots \ldots \ldots \ldots \ldots \ldots$ 1972-PBK-8 30

Figs. 3-4. Elphidium cuvillieri Lévy 1966;

semitransparent specimen; last chamber

missing; sample $250 ; \times 80 \ldots \ldots \ldots \ldots \ldots$ 1972-PBK-9 30

Fig.s 5-6. Elphidium excavatum (Terquem 1875);

sample $111 ; \times 80 \ldots \ldots \ldots \ldots \ldots \ldots \ldots \ldots$ 1972-PBK-10 31

Figs. 7-8. Elphidium excavatum (Terquem 1875)

var. a; sample $223 ; \times 80 \ldots \ldots \ldots \ldots \ldots \ldots$ 1972-PBK-11 33

Figs. 9-10. Elphidium gunteri Cole 1931;

sample $113 ; \times 80 \ldots \ldots \ldots \ldots \ldots \ldots \ldots \ldots$ 1972-PBK-12 33

Figs. 11-12. Elphidium incertum (Williamson 1858);

sample $241 ; \times 80 \ldots \ldots \ldots \ldots \ldots \ldots \ldots \ldots$ 1972-PBK-13 34

Figs. 13-14. Elphidium margaritaceum

Cushman 1930; last chambers missing;

sample $116 ; \times 80 \ldots \ldots \ldots \ldots \ldots \ldots \ldots \ldots$ 1972-PBK-14 35 


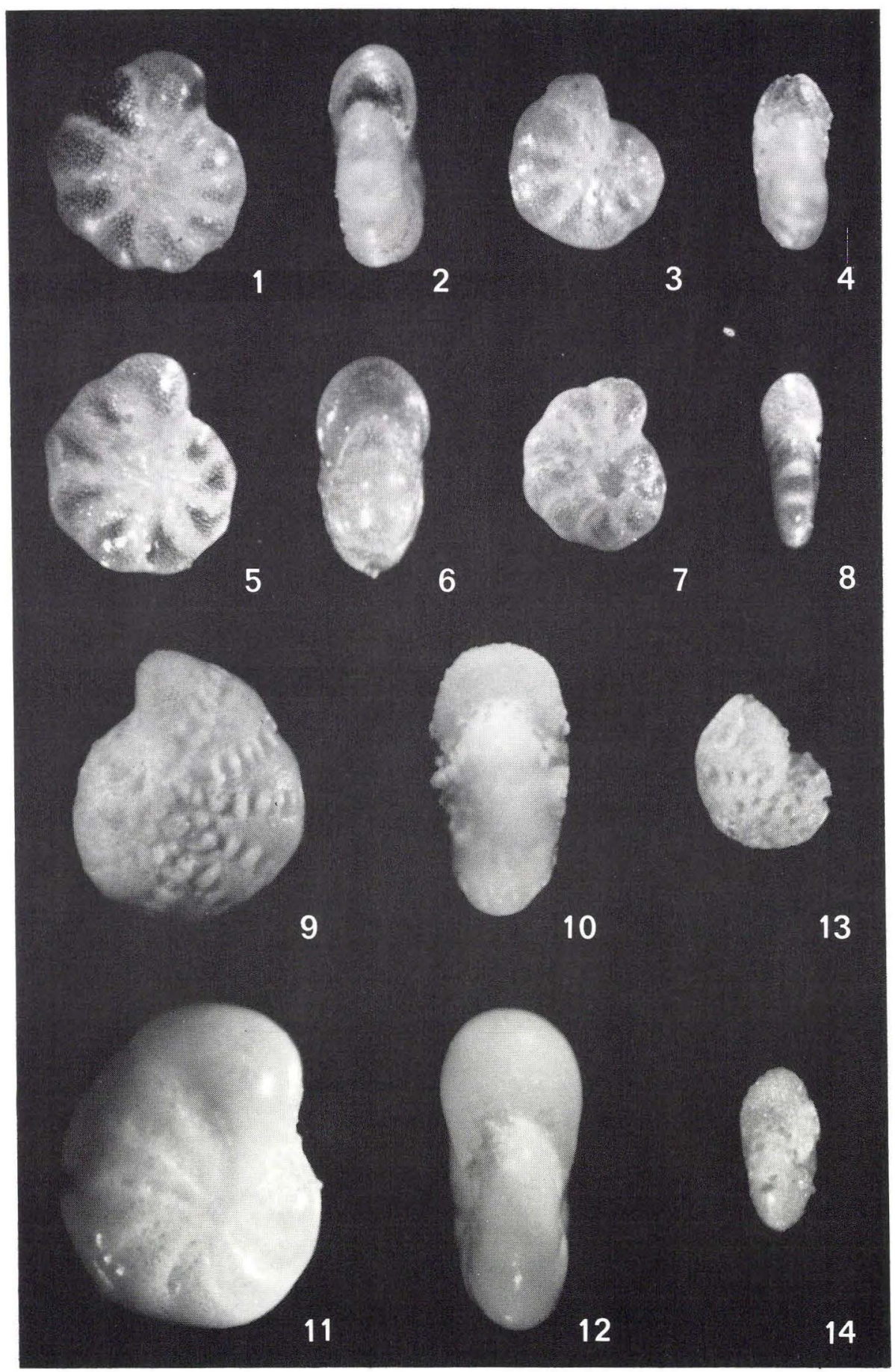


Plate 3

D. G. U. Text

Figs. 1-2. Protelphidium albiumbilicatum Catalogue No, page

(Weiss 1954); sample $109 ; \times 80 \ldots \ldots \ldots$ 1972-PBK-15 36

Fig. 3. Protelphidium albiumbilicatum

(Weiss 1954); sample $110 ; \times 80 \ldots \ldots \ldots \ldots$ 1972-PBK-16 36

Figs. 4-5. Protelphidium anglicum Murray 1965;

last chambers missing; sample $241 ; \times 80 \ldots \ldots$ 1972-PBK-17 39

Figs. 6-7. Protelphidium dittmeri (Lafrenz 1963);

sample $120 ; \times 80 \ldots \ldots \ldots \ldots \ldots \ldots \ldots \ldots$ 1972-PBK-18 39

Figs. 8-9. Protelphidium niveum (Lafrenz 1963);

sample $212 ; \times 80 \ldots \ldots \ldots \ldots \ldots \ldots \ldots \ldots \ldots$ 1972-PBK-20 41

Figs. 10-11. Protelphidium orbiculare

(Brady 1881); sample $111 ; \times 80 \ldots \ldots \ldots$ 1972-PBK-21 42

Figs. 12-13. Protelphidium magellanicum

(Heron-Allen \& Earland 1932);

sample $117 ; \times 80 \ldots \ldots \ldots \ldots \ldots \ldots \ldots \ldots$ 1972-PBK-19 40

Figs. 14-15. Ammonia batavus (Hofker 1951);

sample $219 ; \times 80 \ldots \ldots \ldots \ldots \ldots \ldots \ldots \ldots \ldots \ldots$ 1972-PBK-22 43 


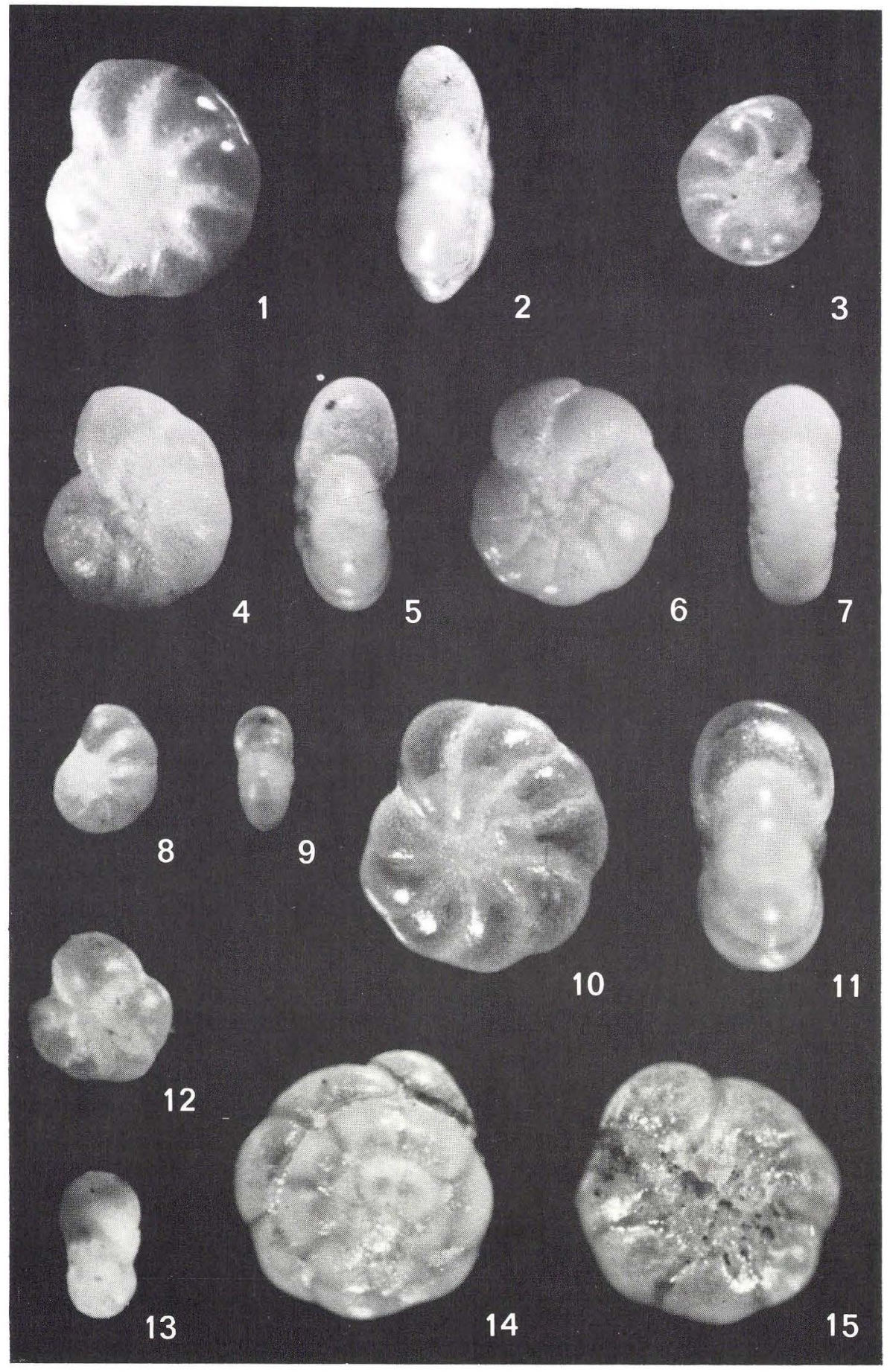


Plate 4

Fig. 1. Nonion depressula (Walker \& Jacob 1798)

D. G. U. Text emend. Murray 1965; side view;

Catalogue No. page sample $241 ; \times 150 \ldots \ldots \ldots \ldots \ldots \ldots \ldots$ 1973-PBK-1 26

Fig. 2. Nonion depressula (Walker \& Jacob 1798) emend. Murray 1965; last chamber missing; view of septum; sample $241 ; \times 250 \ldots \ldots \ldots$ 1973-PBK-2 26

Fig. 3. Elphidium cuvillieri Lévy 1966; side view; sample $250 ; \times 100 \ldots \ldots \ldots \ldots$. 1973-PBK-3 30

Fig. 4. Elphidium cuvillieri Lévy 1966; last chambers missing; view of septum; sample $250 ; \times 250$

Fig. 5. Elphidium excavatum (Terquem 1875); side view; sample $111 ; \times 100 \ldots \ldots \ldots \ldots$

Fig. 6. Elphidium excavatum (Terquem 1875); last chamber missing; view of septum; sample $111 ; \times 250$

Fig. 7. Elphidium excavatum (Terquem 1875) var. a; side view; sample 223; × 100

Fig. 8. Elphidium excavatum (Terquem 1875) var. a; last chamber missing; view of septum; sample $223 ; \times 250$

Scanning electron micrographs. 

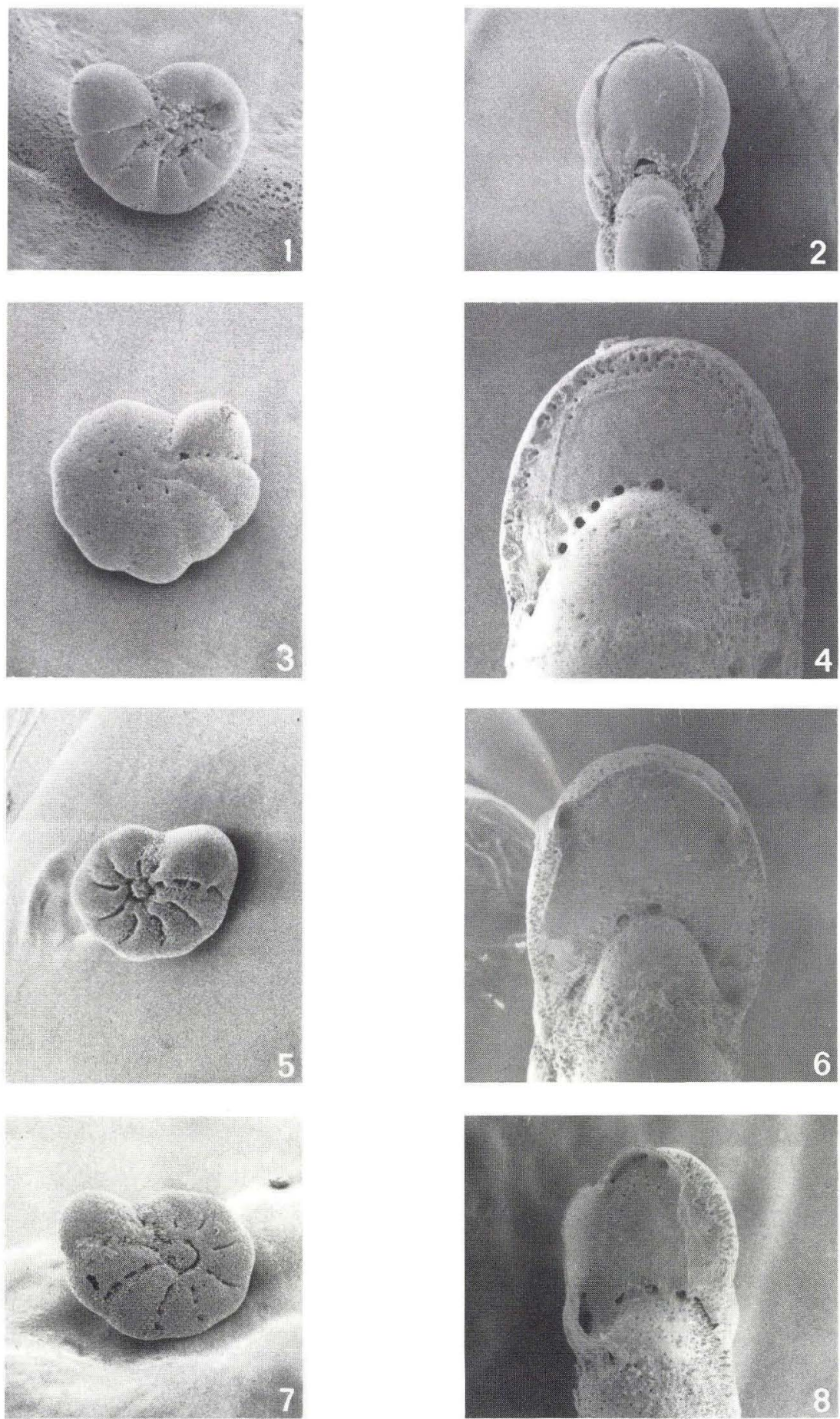
Plate 5

Fig. 1. Protelphidium albiumbilicatum

D. G. U. Text Catalogue No. page

(Weiss 1954); side view; sample 109; × $100 \ldots$ 1973-PBK-9 36

Fig. 2. Protelphidium albiumbilicatum

(Weiss 1954); last chambers missing;

view of septum; sample $109 ; \times 250 \quad \ldots \ldots \ldots$ 1973-PBK-10 36

Fig. 3. Protelphidium dittmeri (Lafrenz 1963);

side view; sample $112 ; \times 100 \ldots \ldots \ldots \ldots$ 1973-PBK-11 39

Fig. 4. Protelphidium dittmeri (Lafrenz 1963);

last chamber missing; view of septum;

sample $112 ; \times 250 \ldots \ldots \ldots \ldots \ldots \ldots \ldots$ 1973-PBK-12

Fig. 5. Protelphidium magellanicum

(Heron-Allen \& Earland 1932);

side view; sample $112 ; \times 100 \ldots \ldots \ldots \ldots$. 1973-PBK-13 40

Fig. 6. Protelphidium magellanicum

(Heron-Allen \& Earland 1932); last chamber

missing; view of septum; sample $112 ; \times 250 \quad \ldots \quad$ 1973-PBK-14 40

Fig. 7. Protelphidium niveum (Lafrenz 1963);

side view; sample $212 ; \times 150 \ldots \ldots \ldots \ldots$ 1973-PBK-15 41

Fig. 8. Protelphidium niveum (Lafrenz 1963);

last chamber missing; view of septum;

sample $212 ; \times 250$

1973-PBK-16 41

Scanning electron micrographs. 

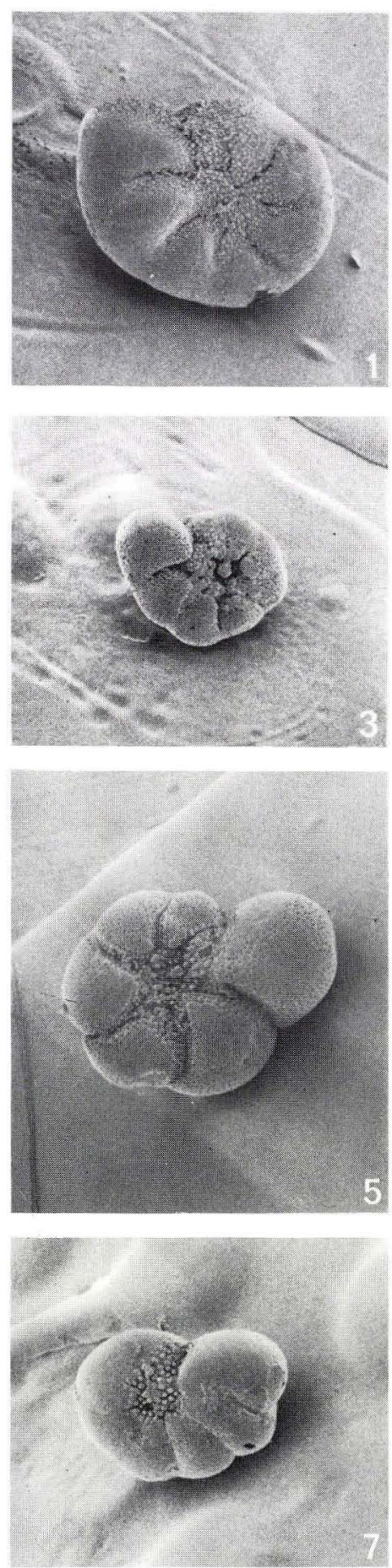

